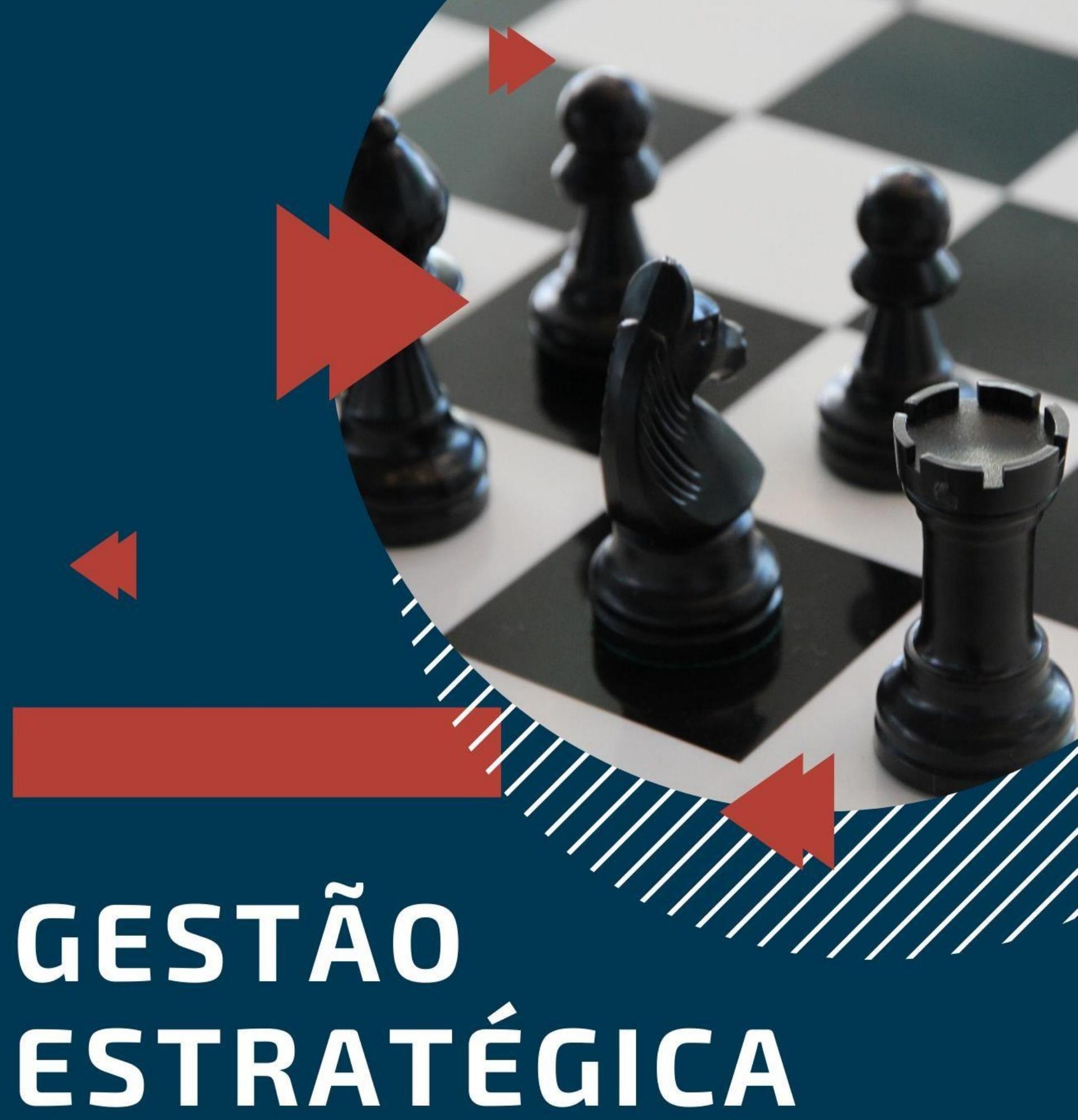

Elizângela de Jesus Oliveira Wanderson da Silva Damião Erick Dawson de Oliveira (Organizadores) 
Organizadores:

Elizangela de Jesus Oliveira

Wanderson da Silva Damião

Erik Dawson de Oliveira

\section{Gestão Estratégica}

1a Edição

Belo Horizonte

Poisson

2020 
Editor Chefe: Dr. Darly Fernando Andrade

\section{Conselho Editorial}

Dr. Antônio Artur de Souza - Universidade Federal de Minas Gerais

Msc. Davilson Eduardo Andrade

Dra. Elizângela de Jesus Oliveira - Universidade Federal do Amazonas

Msc. Fabiane dos Santos

Dr. José Eduardo Ferreira Lopes - Universidade Federal de Uberlândia

Dr. Otaviano Francisco Neves - Pontifícia Universidade Católica de Minas Gerais

Dr. Luiz Cláudio de Lima - Universidade FUMEC

Dr. Nelson Ferreira Filho - Faculdades Kennedy

Ms. Valdiney Alves de Oliveira - Universidade Federal de Uberlândia

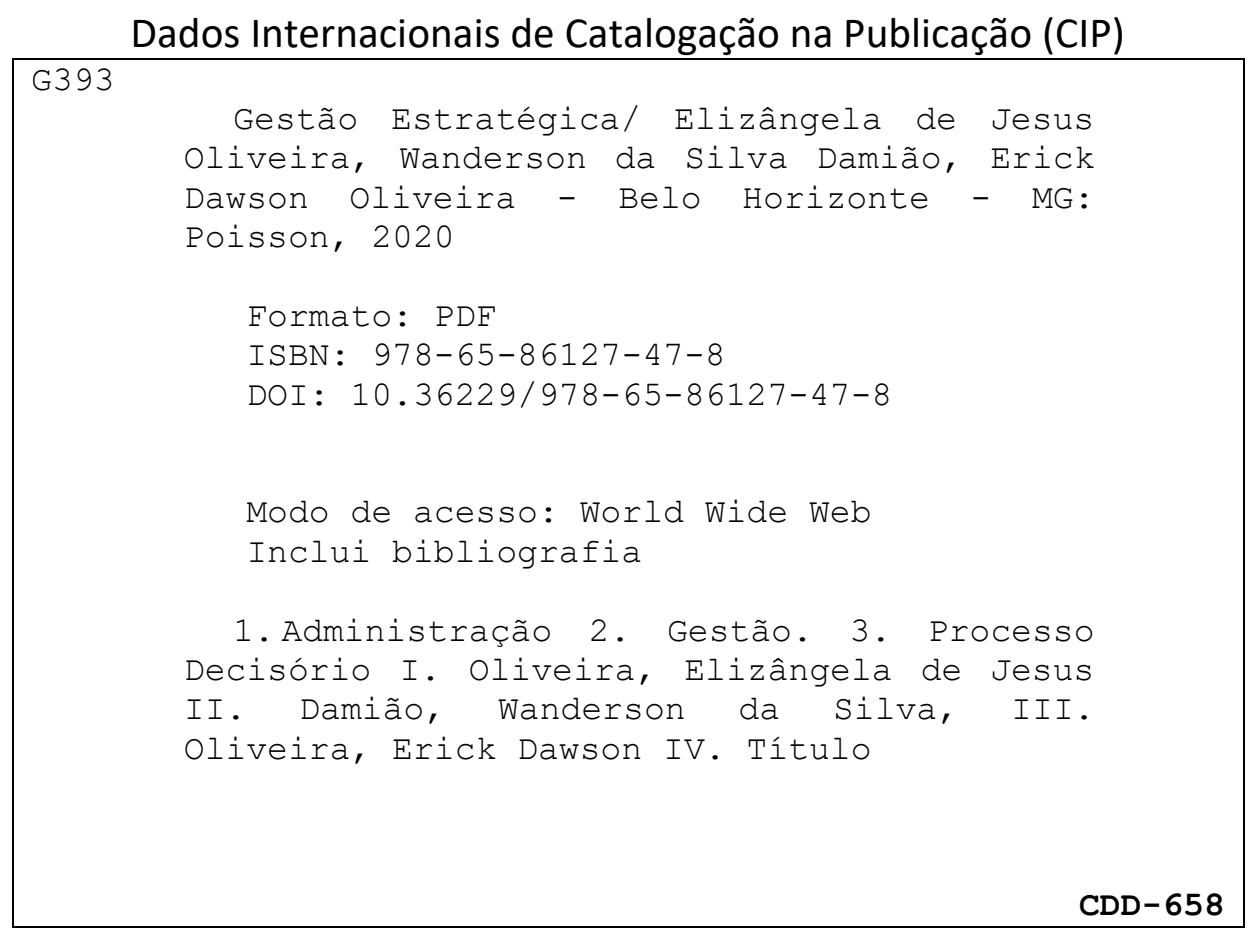

O conteúdo do livro e seus dados em sua forma, correção e confiabilidade são de responsabilidade exclusiva do seu respectivo autor.

www.poisson.com.br

contato@poisson.com.br 


\section{Organizadores}

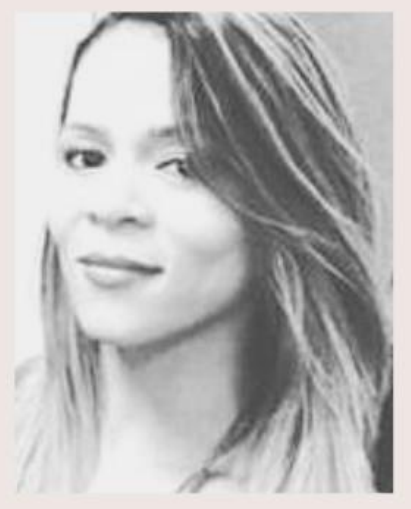

\section{Elizangela de Jesus Oliveira}

Professora Doutora da Universidade Federal do Amazonas. Doutorado em Administração pela UNIMEP - UNIVERSIDADE METODISTA DE PIRACICABA e Mestre em Administração pela FPL -FUNDAÇÃO PEDRO LEOPOLDO DE MINAS GERAIS. Possui graduação em Administração pela UNIMONTES- Universidade Estadual de Montes

Claros (2008). Especialista em Design Instrucional para Educação a Distância pela UNIFEI- Universidade Federal de Itajubál. Possui experiência como docente na Graduação Presencial dos cursos de Administração, Engenharias, e Cursos Superiores em Tecnologia de Logística, Comércio Exterior e Gestão Portuária e Gestão de Recursos Humanos. Estuda o tema felicidade no trabalho nas organizações e desenvolve consultoria na área de gestão de pessoas.

\section{Wanderson da Silva Damião}

Doutorando em Administração na UNIMEP, possui mestrado acadêmico em Administração de Empresas pela UMESP, MBA em Gestão de Pessoas e especialização em Gestão Empresarial e Financeira pela Faculdades Anhanguera, Bacharelado em Teologia pela UMESP. Bacharelado em Teologia pelo Instituto FATEM e Tecnologia Mecânica pelo Centro Universitário de Santo André UNI-A. Exerce atividades de Adminstração, Pesquisa, Docência e Coordenação de cursos EAD no Instituto FATEM, trabalhos técnicos em infraestrutura e equipamentos na Volkswagen do Brasil LTDA. 


\section{Erick Dawson de Oliveira}

Doutorando em Administração Unimep - Linha de Pesquisa - Marketing e Estratégia. Mestre em Gestão de Pessoas e Organizações pela Universidade Metodista de São Paulo UMESP. Professor Assistente D no curso de Bacharel em Administração - Unespar -

Universidade Estadual do Paraná, Campus de Paranavaí. Graduado em Administração de Empresas pela FACINOR Faculdade Intermunicipal do Noroeste do Paraná (2003), Especialização em Gestão Empresarial com foco em Marketing pela Fundação Getúlio Vargas - RJ (2005) e Especialização em Comunicação, Publicidade e Negócios pelo CESUMAR Delegado do Conselho Regional de Administração do Paraná - Jurisdição de Paranavaí-Pr. Coordenador Geral do Projeto Extensão Patronato, Avaliador Ad hoc da Revista Conbrad. Avaliador Ad hoc da Revista de Ciências Empresariais da Unipar. Avaliador do Caderno Profissional de Administração da UNIMEP. Avaliador da Revista RECC. Revista Eletrônica Científica do CRA-PR. 


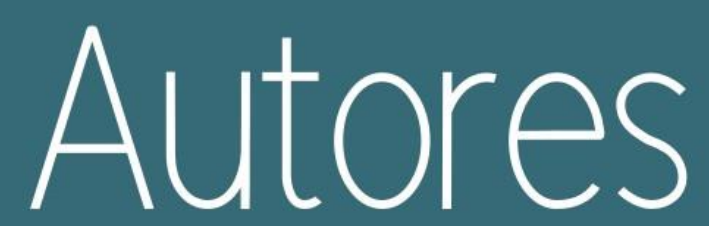

\section{Letícia Soares Carvalho}

Graduada em Gestão de Recursos Humanos e Pós Graduada em Gestão Estratégica de Negócios, ambas pela Universidade Monte Serrat (UNIMONTE), apresentando um excelente desempenho acadêmico, sendo uma das alunas destaque da turma da graduação. Técnica em Administração pela ETEC de Cubatão. Experiência em atendimento ao público através de atividades profissionais e

religiosas, possuindo boa comunicação e facilidade em novos aprendizados. Possui interesse na área de comportamento e desenvolvimento humano.

\section{Vitor Cézar de Oliveira Neto}

MBA - Gestão Estratégica de Negócios na Unimonte, possui Graduação em Gestão Comercial no Centro Universitário UNA Belo Horizonte, formação técnica em Corretor de Seguros pela Escola Nacional de Seguros. Exerce atividade de diretor comercial na empresa Valor Consultoria e Corretagem de Seguros. 


\section{Gabryella Nogueira}

Graduada em Tecnólogo em Gestão de Recursos Humanos pelo Centro Universitário Monte Serrat UNIMONTE, e pós graduada em MBA Gestão Estratégica em Negócios (UNIMONTE). Já atuou como Gerente em uma rede de Fast Food. Atualmente atua, como Assistente Administrativa em uma empresa de microcrédito. Interessa-se por Relações Públicas e Comunicação Corporativa.

\section{Shuster Almeida}

Graduado no curso Tecnólogo em Gestão de Recursos Humanos, com pós graduação em Gestão Estratégica de Negócios pelo Centro Universitário Monte Serrat (Unimonte). Ótimo rendimento como universitário, sendo um dos alunos destaques da graduação. Grande apreço pela área tecnológica, com foco na tecnologia da informação. 


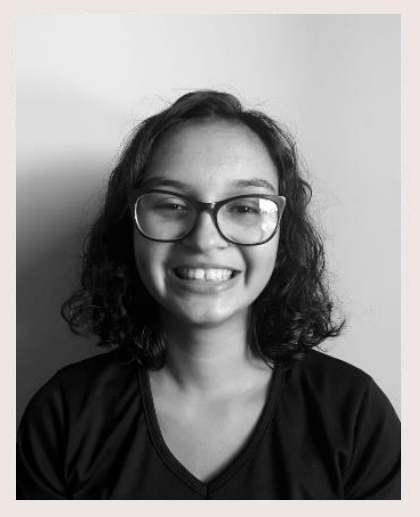

\section{Alice Rocha}

Graduada em Engenharia de Produção pelo Instituto de Ciências Exatas e Tecnologia da Universidade Federal do Amazonas, mestranda em Engenharia Mecânica pelo Programa de Pós-Graduação em Engenharia Mecânica da Universidade Federal de Santa Catarina. Desenvolveu trabalhos em Engenharia do produto, Extensometria e Gestão Estratégica.

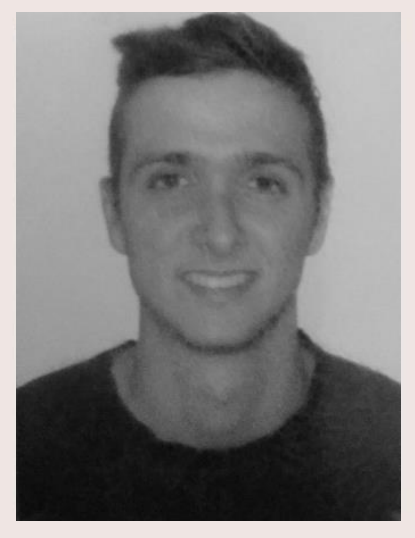

\section{Victor Dias}

Victor Yan Bufoni Dias, natural de Santos/SP, 24 anos, militar, solteiro, técnico em Logística, possui as graduações em Ensino Superior em tecnologia em Logística, tecnologia em Comércio Exterior, tecnologia em Gestão de Portuária e especialista MBA em Gestão Estratégica em Negócios pelo Centro Universitário São Judas Tadeu - Santos/SP. 


\section{Prefácio}

Dentro de uma abordagem acadêmica bem elucidativa e simples, o objetivo desse livro foi abordar temas correlatos à dinâmica organizacional. Dessa forma, quaisquer profissionais de áreas diversas ou correlatas às ciências sociais aplicadas poderão compreender a importância do processo de comunicação dentro das organizações e a percepção dos colaboradores sobre o processo de retroalimentação ou feedback. São abordados ainda, conceitos teóricos sobre o clima organizacional e apresentado o resultado de uma pesquisa que realizou um estudo de caso sobre a importância do clima organizacional como um diferencial estratégico na gestão da qualidade da prestação de serviços. Nesse capítulo os autores ressaltam para um resultado que indicou que o clima organizacional pode ser utilizado como estratégia pelos gestores, a fim de gerar resultados para tomada de decisões. Trata-se ainda de um livro que vai para além das fronteiras de outras atividades organizacionais ou empresariais, pois ainda apresenta o uso das tecnologias de informação no ambiente acadêmico, demonstrando que dentro de uma universidade que apresenta uma arquitetura organizacional peculiar as tecnologias de informação podem agregar valor ao cliente final. Esse processo de geração de valor é refletido nesse caso, através do aumento da aprendizagem do discente, resultado esse de fundamental importância para o processo de tomada de decisão relacionado aos modelos que devem ser implementados nas universidades com vistas a aprimorar a aprendizagem dos discentes. Ainda dentro do ambiente acadêmico, os autores discorrem sobre a importância da inteligência emocional na percepção de jovens universitários. Os autores apontaram que os jovens universitários que participaram da pesquisa reconheceram a necessidade da busca pelo equilíbrio emocional como forma de se alcançar objetivos e metas de vida profissional e pessoal.

Portanto, recomenda-se esse livro para profissionais iniciantes e que pesquisam por temas relacionados à gestão de pessoas como, por exemplo, a comunicação corporativa, clima organizacional, aprendizagem utilizando tecnologias de informação e percepção da inteligência emocional como fator estratégico.

\section{Profa Dra Elizângela de Jesus Oliveira}




\section{Sumário}

Capítulo 01 - O Papel Estratégico Da Comunicação Corporativa Elizangela de Jesus Oliveira, Wanderson Silva Damião, Erick Dawson de Oliveira, Gabryella Aparecida

Franco Nogueira

DOI: 10.36229/978-65-86127-47-8.CAP.01

Capítulo 02 - Clima Organizacional: Um Diferencial Estratégico na Gestão da Qualidade

e Serviços na Empresa Valor Seguros

Elizangela de Jesus Oliveira, Wanderson Silva Damião, Erick Dawson de Oliveira, Vitor Cezar Oliveira Neto

DOI: 10.36229/978-65-86127-47-8.CAP.02

Capítulo 03 - O Uso da Tecnologia da Informação no Processo de Construção da Aprendizagem: Um Estudo de Caso da Percepção de Docentes Universitários

Elizangela de Jesus Oliveira, Wanderson Silva Damião, Erick Dawson de Oliveira, Shusther Azevedo Almeida

DOI: 10.36229/978-65-86127-47-8.CAP.03

Capítulo 04 - A Importância da Inteligência Emocional no Ambiente Corporativo

na Visão de Jovens Universitários

Elizangela de Jesus Oliveira, Wanderson Silva Damião, Erick Dawson de Oliveira, Letícia Soares

Carvalho

DOI: 10.36229/978-65-86127-47-8.CAP.04

Capítulo 05 - A Inserção de uma Ferramenta Operacional Tecnológica no Processo de Movimentação Logística de Contêineres e a Administração na Empresa Estrada em Santos/SP

Elizangela de Jesus Oliveira, Victor Yan Bufoni Dias, Alice Nascimento Teixeira Rocha

DOI: 10.36229/978-65-86127-47-8.CAP.05 


\section{Capítulo 1}

\section{O papel estratégico da comunicação corporativa}

\section{Elizangela Oliveira Jesus}

Wanderson Silva Damião

Erick Dawson de Oliveira

Gabryella Aparecida Franco Nogueira

Resumo: Este estudo de caso tem como finalidade identificar como a comunicação corporativa tem papel fundamental nas organizações, permitindo desenvolver métodos e formas de gestão alinhados com os resultados organizacionais. Pode se afirmar ainda, que uma comunicação clara e objetiva contribui, para tornar mais elucidativo o processo de construção do Feedback nas empresas. A partir disso, foi realizado um estudo descritivo e quantitativo, sendo que os dados foram coletados por meio de questionário aplicado aos funcionários de uma Instituição de Ensino Superior da Baixada Santista. Tomando-se como referência um universo de 40 colaboradores obteve-se amostra, de 20 respondentes. Os dados foram analisados a partir de uma estatística simples. Assim pôde-se inferir que $86 \%$ dos colaboradores afirmaram que o Feedback é o método mais apropriado para melhora no desempenho individual. 


\section{INTRODUÇÃo}

A comunicação quando não explorada de forma estratégica traz consigo uma série de necessidades e desvantagens quando não realizada com base nas ferramentas estratégicas da comunicação.

A informação e a comunicação têm cada vez mais, assumido um papel importante na prática de gestão empresarial e no mundo globalizado. Dessa forma, as práticas comunicacionais permitem às empresas desenvolverem suas estratégias de negócios contribuindo com a motivação, os resultados organizacionais, o desempenho em equipe, a capacidade de atender prontamente as tendências e as demandas do mercado, e servindo de suporte para entrada de novos processos.

É importante compreender a amplitude do cenário atual, é necessário que haja uma visão apurada para alcançar os pré-requisitos e desafios que as empresas passam quando não alinham sua comunicação.

A origem etimológica do termo comunicação vem do latim communicatio, do qual distinguimos sua raiz munis, que significa "estar encarregado de", o prefixo "co" que expressa simultaneidade e o sufixo "tio" que reforça a idéia de atividade primeiro sentido efetivamente relacionado a comunicação estava ligado a "atividade realizada conjuntamente" (WOLF, 2003), e de certa forma, este sentido permeia o processo de comunicação até os dias atuais. Mas quando estamos nos referindo a especificidade da comunicação humana, precisamos nos afastar da definição genérica encontrada nos dicionários e entender que a cultura e o contexto simbólico é que definem o sentido da comunicação, conforme explica Hohfeldt (2001 p. 41) “a comunicação é um processo social básico de produção e partilhamento do sentido através da materialização de formas simbólicas".

A partir dessas reflexões teóricas, esse estudo busca responder as seguintes questões: Até quando a comunicação empresarial permanecerá falha no que diz respeito as relações rotineiras, como nos erros ao abordar o "famoso" feedback?

É necessário alinhar uma comunicação eficaz para que isso não traga resultados e/ou consequências negativas. Assim o objetivo geral desse estudo é ressaltar que todos compreendam que a comunicação tem um papel estratégico que precisa ser definido em qualquer organização.

Ao observar todas essas informações com base em pesquisas bibliográficas e estudo, os resultados alcançados poderáo auxiliar as organizações a trabalhar de forma eficaz preparando internamente meios de estabelecer uma comunicação que bem sucedida trará não só melhoria no desempenho pessoal, mas sim, resultados organizacionais.

Dessa forma esse este estudo está estruturado em mais quatro seções: referencial teórico, metodologia, apresentação e discussão dos resultados e conclusões.

\section{APORTE TEÓRICO}

\subsection{COMUNICAÇ̃̃O CORPORATIVA}

Em virtude das novas exigências de mercado e constantes mudanças, a comunicação empresarial se faz de suma importância como instrumento para dar suporte e para operacionalizar estas mudanças no macro e 
micro ambiente. Na visão de Kunsch (2003, p.149) "Comunicação Organizacional, Comunicação Empresarial e Comunicação Corporativa” são terminologias usadas indistintamente no Brasil para designar todo trabalho de comunicação levado a efeito pelas organizações em geral. Antes de adentrar a respeito da comunicação a partir do âmbito organizacional, é necessário relembrar sua origem e história. A própria história da humanidade é decorrente de um processo evolutivo e a comunicação já era reproduzida em sua linguagem por meio de sinais, sons, expressões e grunhidos pelo elemento da linguagem rudimentar ou seja, era fundamental algum meio que permitisse as pessoas falarem ou transmitir determinado tipo de informação para seus objetivos fins.

A comunicação nos permite interatividade entre os grupos humanos e nos conduziu gradativamente para o progresso pela transmissão do conhecimento. Corroboram com esta visão Weick, Sutcliffe e Obstfeld (2005), ao afirmarem que o processo principal na determinação na definição da Comunicação Corporativa surge através do comportamento humano, por ser onde materializa a compreensão que informa e define a identidade e a ação das pessoas nas organizações.

O princípio da história do homem é a história da comunicação propriamente dita, a relação que as pessoas tinham com o tempo foi modificando-se. Segundo Pimenta (2002), a escrita é resultado de descobertas e experiências anteriores, por ela, o homem começa um relacionamento mais amplo e diferente, o que o conduziu a uma evolução mais rápida. Ele passa a armazenar, transportar, difundir e perpetuar o conhecimento, a sua história começa a ser registrada oficialmente.

Apesar disso, já era possível perceber como naquela época a comunicação já se fazia presente, assim como, ressalta a utilização da comunicação verbal e a não verbal. Através dessa evolução é possível enxergar a história da comunicação atual humana e como se sucede fora e principalmente dentro das organizações, a urgência em utilizar uma linguagem clara e objetiva e o resultado ou ruído que pode trazer boas ou más consequências quando não reproduzida de forma planejada, estratégica e bem formulada.

Para Chiavenato (2005) dentro dos preceitos a comunicação é vital e indispensável para o comportamento das organizações, dos grupos e das pessoas; é a partir dela que os seres compartilham informações entre si, tornando o ato de se comunicar uma atividade essencial.

Em contrapartida salienta Torquato (2002, p. 162) "o poder da comunicação pode ser designado como poder expressivo. Ele é capaz de alterar estados de comportamentos e, dependendo das formas como é utilizado, poderá ser decisivo para o tipo de participação do funcionário e para eficácia global dos programas empresariais". Como discorre o escritor, a forma de empregar a comunicação repercute e contrapõe muito mais do que a própria mensagem transmitida.

Conforme os escritores evidenciam, é de modo inerente nos últimos tempos a atenção e o controle da comunicação existente, sendo de forma indispensável o estudo da comunicação dentro da organização.

Pretende-se que através destas práticas adotadas, definindo uma comunicação conforme seu público alvo ou stakeholders, seja alinhada e propicie um ambiente de trabalho onde estejam alinhados entre superiores, gerentes, e colaboradores formas de se comunicar em diferentes linhas hierárquicas adotando o modo mais adequado para cada uma delas, conforme a cultura daquela organização. Na visão de 
Bateman e Shell (2006), eles ressalvam esse tipo de comunicação como fluxo de informações que parte dos níveis baixos para os altos, fazendo com que todos percebam e compreendam a necessidade das informações transmitidas, para desempenhar funções e tarefas, tornando se fiéis a organização.

Ao refletir sobre o que se subentende por comunicação dentro de uma organização, observa-se que possam existir vários fluxos, ou seja, maneiras diversas vista que a comunicação é multidirecional e baseia-se de acordo com a estrutura da empresa. Todas organizações possuem uma estrutura, uma hierarquia a ser seguida, assim como em um organograma, por meio de uma única imagem é possível ver toda a disposição de departamentos,setores e cargos de uma empresa.

Robbins (2002), traz a visão de um dos indicadores que facilitam o desempenho interno e externos ao abordar a questão da estrutura organizacional, quando cita a motivação como o processo responsável pela intensidade, direção e persistência dos esforços de uma pessoa para o alcance de determinado objetivo.Esta medida auxilia alta gerência como medir, se estes esforços estão sendo favoráveis à organização,Robbins (2002) ainda acrescenta ao dizer que os indivíduos motivados se mantêm na realização da tarefa até que os objetivos sejam alcançados.

Pra isso se faz necessário coordenar os componentes da comunicação, ou seja, é através das informações que as organizações se norteiam fazendo a integração de suas partes e se solidificam no mercado. Deste modo, divide-se o processo de comunicação, quanto ao movimento, em duas partes, comunicação vertical, subdividida em ascendente e descendente, e a horizontal, também conhecida como lateral.

Para melhor compreensão a figura 1 abaixo demonstra como este processo funciona:

Figura 1 - Maneiras de como a Empresa direciona a sua comunicação

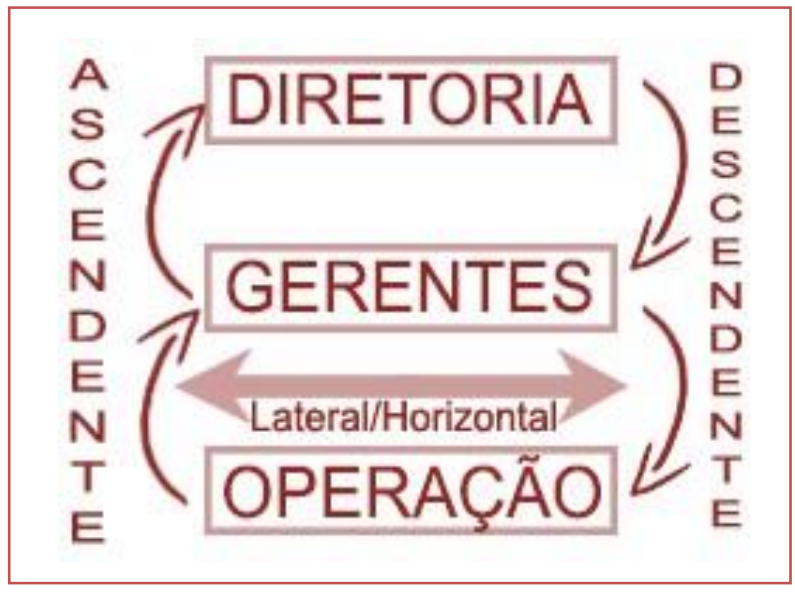

Fonte: Elaborado pelo autor

Ao observar a figura acima, é possível perceber como ocorre o fluxo de comunicação, como é importante alinhar e definir meios e estratégias pois coopera inteiramente para as necessidades internas da empresa, bem como as informações que auxiliam no crescimento da mesma.

Para que se estabeleça estratégias e seus papéis na construção dessa prática de comunicação empresarial ou coorporativa, nas próxima seção irá abordar os papéis estratégicos. 


\subsection{PAPÉIS ESTRATÉGICOS DA COMUNICAÇÃO}

Assim como foi citado anteriormente a base que sustenta as relações de uma comunicação efetiva são estratégias, formular uma estratégia não é bem como um plano. Trata-se de uma sequência de etapas que permite a organização refletir, decidir, e debater seus propósitos para assegurar suas táticas fundamentais, de acordo com seus interesses organizacionais.

Para o autor Chiavenato (1999), este processo de formulação e planejamento tem como ponto de partida a determinação sistemática de objetivos estratégicos e de estratégias para atingi-los. Ou seja, os planos estratégicos geralmente de longo prazo, envolvem decisões de alto impacto organizacional e despendem grande volume de recursos na busca dos macro objetivos da empresa.

Vale observar que, a comunicação empresarial não flui de forma isolada assim como também a formulação das estratégias, portanto é necessário, que todos os departamentos como Recursos Humanos e os demais setores estejam alinhados com a prática e a cultura da organização.

A filósofa Margarida Kunsch (2009) afirma ao dizer que, no ambiente de trabalho a comunicação forma um ciclo integrado, envolvendo todas as áreas organizacionais em prol de ações sinérgicas e com mesmos desígnios. Portanto, as iniciativas tomadas internamente com meu público interno, ou seja, os colaboradores, certamente refletirão no público externo, contribuindo ou não para o posicionamento da empresa no mercado, com isso é necessário instituir boas práticas, um clima saudável dentro da organização, e criar relações com funcionários, colaboradores, e clientes, construir uma imagem positiva.

E para tornar um ambiente saudável é preciso ser assertivo no que diz respeito às relações, para mensuração desse retorno, só é possível através do feedback que será abordado na seção a seguir.

\subsection{FEEDBACK}

Ao citar a comunicação, é apropriado recordar do termo feedback, ambos fazem parte do processo da comunicação, é eficaz para melhora no clima organizacional e consequentemente o desempenho humano.

De acordo com o Dicionário Aurélio a palavra Feedback vem da língua inglesa, e tem como significado reação a um estímulo; resultado retroativo que atinge o momento anterior à sua ocorrência; em outras definições fala; resposta enviada à origem sobre resultado de uma tarefa que já foi realizada; resposta.

Segundo Pinho (2006) afirma, que a comunicação se dá por um processo no momento que o emissor emite a mensagem ao receptor, por um meio e através de um canal e o será Feedback a resposta daquilo que chegou, considerar que até chegar ao receptor pode existir algum tipo de ruído. Ou seja, é onde perpetua a maior parte das falhas na comunicação, seja por quem emite ou quem absorve a mensagem.

O Feedback é uma ferramenta que serve como base para a gestão e para o bom desempenho de uma organização, é através dela que se mede e filtra resultados, torna a empresa mais enxuta, forte, lucrativa e estruturada. Contudo, ainda que exista esse tipo de suporte existem organizações que não são adeptas ou não utilizam de forma adequada e coesa. 
A forma de conduzir e dirigir vai ao encontro com a prática do feedback e o modelo de gestão, os papéis estratégicos e a estrutura organizacional precisam estar definidas e alinhadas para que haja sinergia. Assim como apoia Willians (2005), que a comunicação assim como o feedback mantêm as pessoas informadas, explica as decisões e políticas com cordialidade e transparência.

Na próxima seção apresenta-se a metodologia utilizada para a realização da pesquisa empírica.

\section{METODOLOGIA}

Para alcançar o objetivo proposto foi realizada pesquisa descritiva e quantitativa em uma instituição de Ensino Superior da Baixada Santista.

Segundo Oliveira (1999), a pesquisa descritiva exige planejamento, para definição de métodos e técnicas para coleta e análise de dados, e que utilize de informações obtidas por meio de estudos exploratórios.

Para Fonseca (2002) contrapartida já a pesquisa qualitativa, os resultados podem ser quantificados. Como as amostras geralmente são grandes e consideradas representativas da população, os resultados apurados são como se formassem um retrato real de toda a população alvo da pesquisa. A pesquisa quantitativa se concentra na objetividade, entusiasmada pelo positivismo, considera que a realidade só pode ser compreendida com base na análise de dados, apurados através de padronização e recursos neutros, nela contém a linguagem matemática para descrever as causas de um fenômeno e as relações entre variáveis como por exemplo. A utilização de ambas qualitativa e quantitativa permite recolher mais informações do que se poderia conseguir isoladamente.

Quanto ao método utilizado, o presente estudo pode ser classificado como estudo de caso Yin (2005) afirma, que a utilização do estudo de caso é apropriada quando se pretende investigar o como e ou porquê de um conjunto de acontecimentos contemporâneos, é uma forma de investigação empírica que permite o estudo de um fenômeno contemporâneo dentro de seu contexto real, especialmente quando os limites entre o fenômeno e o contexto não estão claramente definidos.

A coleta de dados foi realizada por meio de questionário, de acordo com Gil (1999) é a técnica utilizada para reconhecer opiniões, como um processo de investigação de sentimentos e experiências das pessoas.

Quanto à amostragem, foi a probabilística aleatória de acordo com (MERRILL 1977), são amostras em que os componentes são extraídos da população de acordo com probabilidades pelo qual os membros são selecionados e especificado antes de iniciada a amostragem e não deixa ao investigador qualquer margem para decidir que itens da população devem ser incluídos na amostra. A figura abaixo demonstra a metodologia desta pesquisa: 
Figura 2 - Diagrama

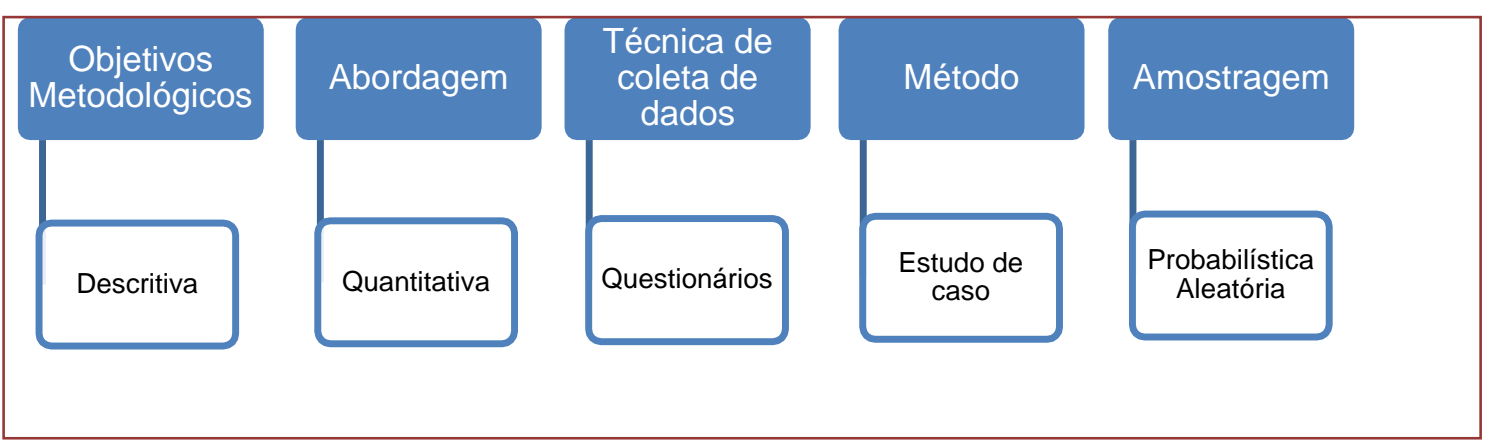

Fonte: Elaborado pelos autores

A figura 2 acima, demonstra de maneira ordenada e objetiva a construção deste artigo, os métodos utilizados e objetivos principais como Comunicação e Feedback, explorando a importância percebida através do questionário.

Através da metodologia adotada, foi necessário obter informações de funcionários da Instituição de Ensino Superior da Baixada, para que fosse aprofundado o foco central do artigo que é medir estatisticamente se a comunicação é efetiva e se de fato ela contribui para que a empresa gire, ou seja, funcione de forma eficaz contrapartida, evidenciar a importância do Feedback como suporte na organização.

A seguir, a apresentação dos resultados obtidos na pesquisa e o conteúdo observado.

\section{APRESENTAÇÃO E DISCUSSÃO DOS RESULTADOS}

Na metodologia, conforme mencionado acima para a coleta de dados foram utilizados questionários, de 40 questionários que foram distribuídos entre colaboradores da Instituição do Ensino Superior, 20 foram devolvidos respondidos. A partir da tabulação foram elaborados gráficos, com a finalidade de tornar a análise prática e para alcançar uma leitura como resposta ao objetivo do artigo.

Na próxima seção serão declarados os resultados obtidos a partir da coleta de dados, de acordo com Cordeiro (1999), a declaração dos resultados envolve os valores numéricos apresentados por gráficos ou tabelas.

Conforme mencionado acima, observe abaixo a tabulação e os resultados apresentados nos gráficos a seguir. Nesse sentido, quando se perguntou sobre Feedback, o grafico 1 aponta os seguintes resultados: 
Gráfico 1 - Utilização do Feedback

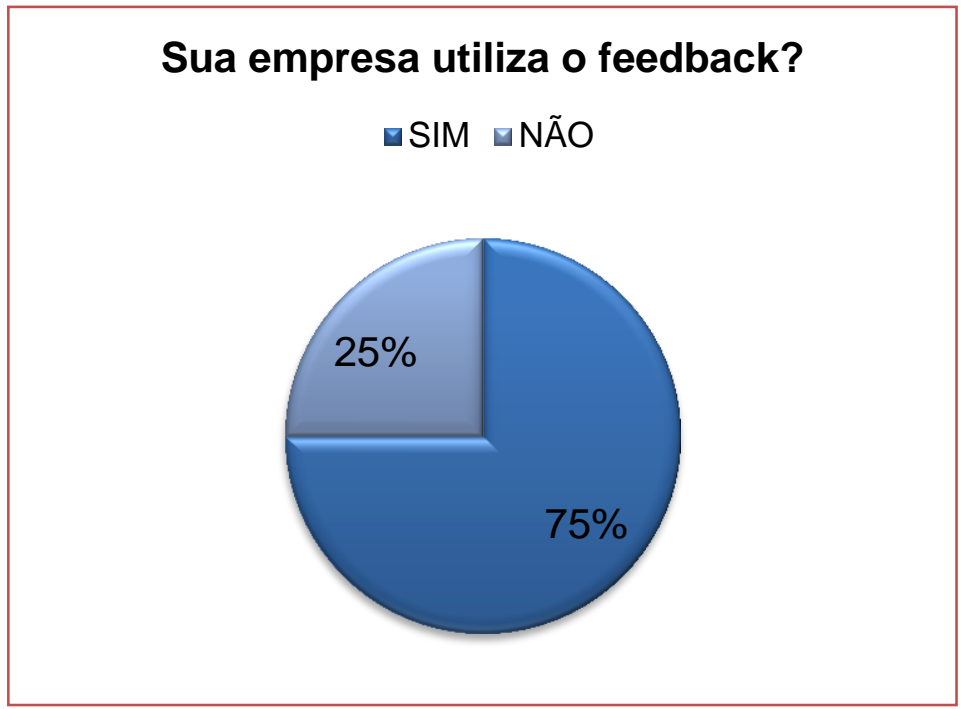

Fonte: Elaborado pela autora

Pode-se inferir que o gráfico 1 entre os questionamentos apurados, percebe-se que $75 \%$ das Instituição de Ensino Superior da Baixada Santista adotam o uso do Feedback, e afirmam ao dizer que a ferramenta se faz necessária para que eles percebam se estão entregando aquilo que é exigido, ou seja, serve como uma base de parâmetro para medir os esforços e se o resultado está sendo satisfatório, caso não seja, eles apontaram que o Feedback é fundamental para direcionar melhorias. Assim como apoia Willians (2005), que a comunicação assim como o feedback mantêm as pessoas informadas, explica as decisões e políticas com cordialidade e transparência, os respondentes apontaram para os seguintes resultados apresentados no gráfico 2, a seguir:

Gráfico 2 - Como reage ao receber o Feedback

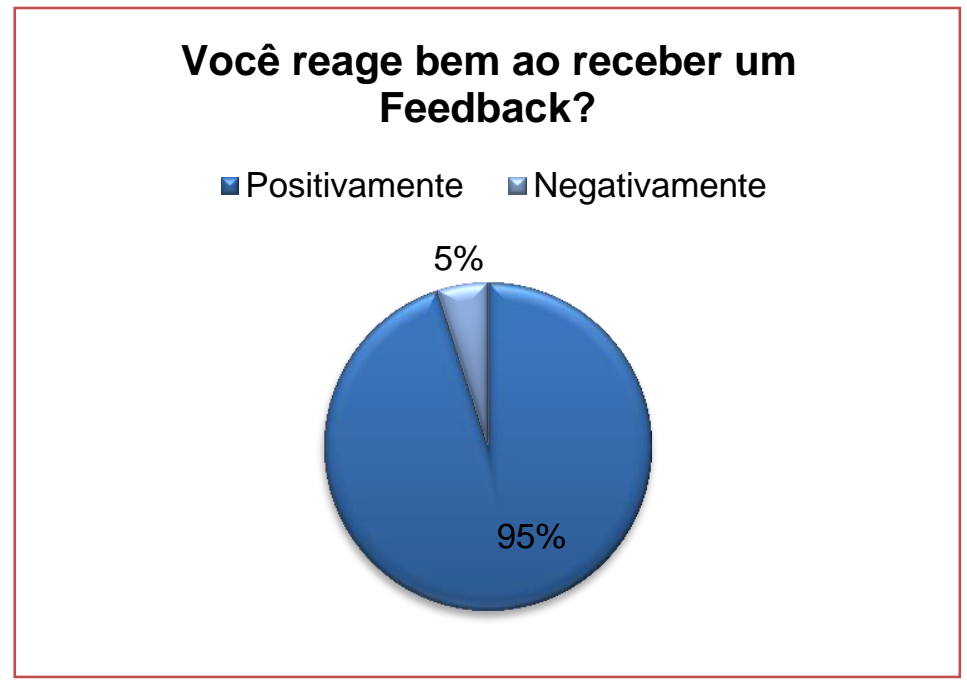

Fonte: Elaborado pela autora 
Observa-se que no gráfico 2, em resposta a questão do Feedback para melhor leitura se a organização utiliza, é preciso entender como estes mesmos funcionários reagem, para que a prática desse retorno seja constante, e 95\% responderam que reage bem, assim como afirma a filósofa Margarida Kunsch (2009), que no ambiente de trabalho a comunicação forma um ciclo integrado, envolvendo todas as áreas organizacionais em prol de ações sinérgicas e com mesmos desígnios. Ou seja, é necessário que haja uma contribuição de ambas as partes para que forme um ciclo integrado, o gráfico 3 a seguir questiona a relação do Feedback como ferramenta no processo de desenvolvimento individual.

Gráfico 3 - Feedback como ferramenta para desenvolvimento

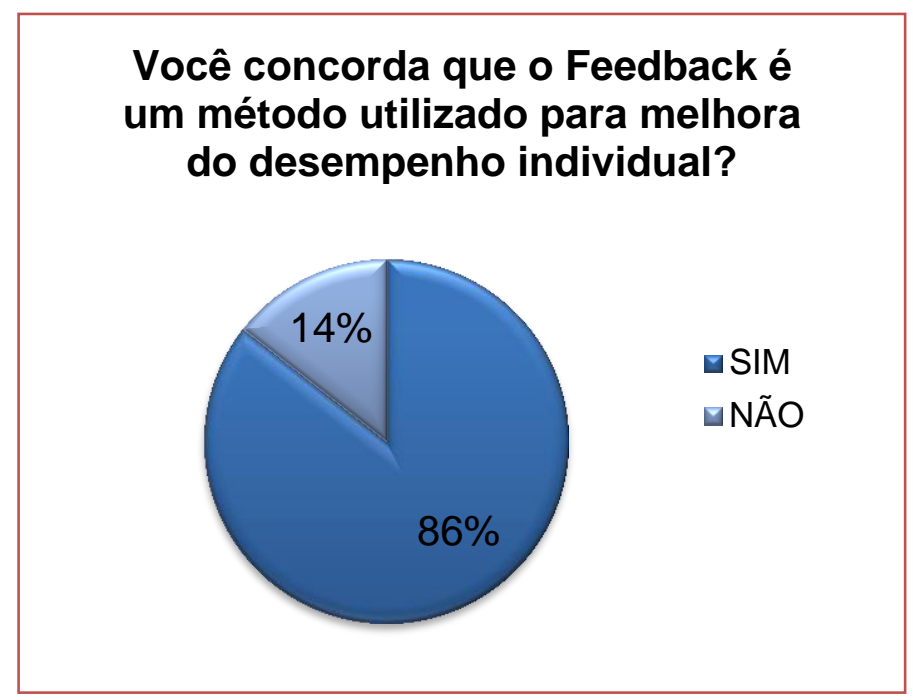

Fonte: Elaborado pela autora.

Ao perguntar se o Feedback era um método que contribui para melhora do desempenho individual, $86 \%$ concordaram sendo os demais $14 \%$ que não apoiam este conceito alegavam não perceber o gestor de forma positiva, portanto não tinham uma comunicação coesa, então não tinham uma visão correta, salienta Torquato (2002, p. 162) "o poder da comunicação pode ser designado como poder expressivo. Ele é capaz de alterar estados de comportamentos e, dependendo das formas como é utilizado, poderá ser decisivo para o tipo de participação do funcionário e para eficácia global dos programas empresariais". Já no que refere-se a comunicação podemos observar no gráfico 4 abaixo:

De forma representativa e curiosa ao analisar o gráfico acima, responderam $50 \%$ boa e $50 \%$ ruim, o que demonstra essa divisão de opiniões e no que diz respeito aos ruídos da comunicação, o que ao final se torna alarmante e deficitária, assim como ressalta Robbins (2007), destacando que a comunicação possui quatro funções na organização: controle (mediante a hierarquia pré-disposta pela instituição), motivação (transparência de informações mediante os colaboradores, emissão de retroação e contribuição para melhoria contínua), expressão emocional (relacionamento aproximado entre os colaboradores) e informacional (emissão de informações que contribuem para tomada de decisões).

Portanto, é preciso que haja uma comunicação adequada, e direcionada de e para quem deseja e de acordo com a mensagem que queira transmitir para minimização do ruído. 
Gráfico 4 - Comunicação Corporativa

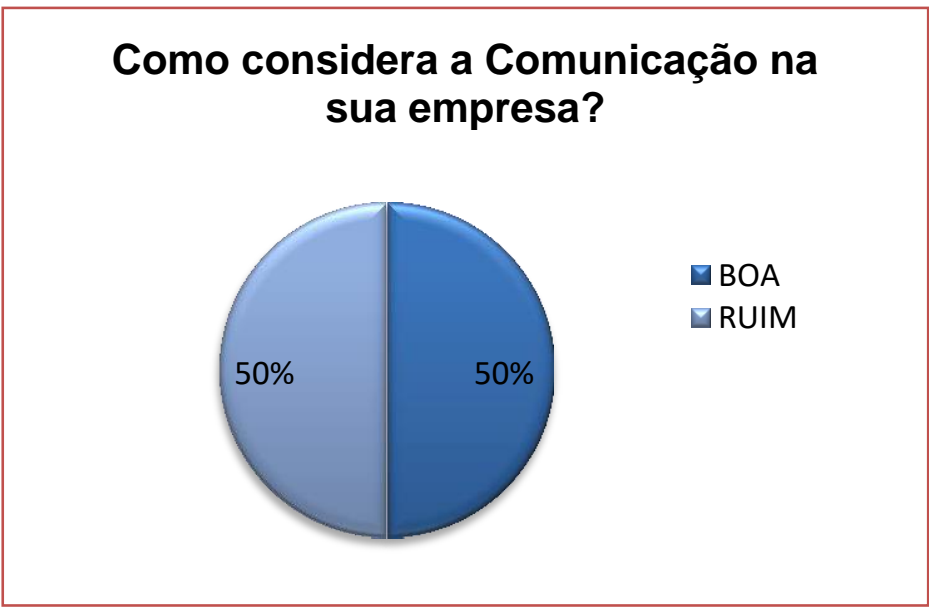

Fonte: Elaborado pela autora.

E ao abordar a questão da comunicação e a aplicação do feedback é preciso atentar-se de que forma é realizada e a postura dos gestores, medir se de fato existe um comportamento adequado para tal, através do gráfico 5 podemos avaliar, de acordo com a opinião dos colaboradores:

Quando perguntamos na opinião deles, a postura do gestor ao aplicar o Feedback era de maneira adequada, $23 \%$ responderam que não e os demais ao relatar suas observações de acordo com seu ponto de vista mesmo colocando no papel que sim, no fundo discordaram dizendo que a postura deles tinham pontos críticos e que falham muitas vezes em não executar o Feedback da maneira com que esperam, ao final do expediente aguardam por um Pós Plantão, ou uma reunião e não são acompanhados, contudo, ficam sedentos por mais informações que possam contribuir para seus esforços e rendimentos e por muitas vezes mesmo sabendo que executam suas tarefas diárias de maneira ética, aguardam uma mensuração desses projetos e trabalhos realizados e passam dias e semanas sem fazer se estão fazendo da forma correta. Outra contribuição, foi dito que isso diz muito a respeito dos resultados organizacionais, eles se comprometem com os resultados e posteriormente querem saber se estão trilhando o caminho correto, ou até mesmo se está próximo de atingir estes resultados.

Gráfico 5 - Gestão

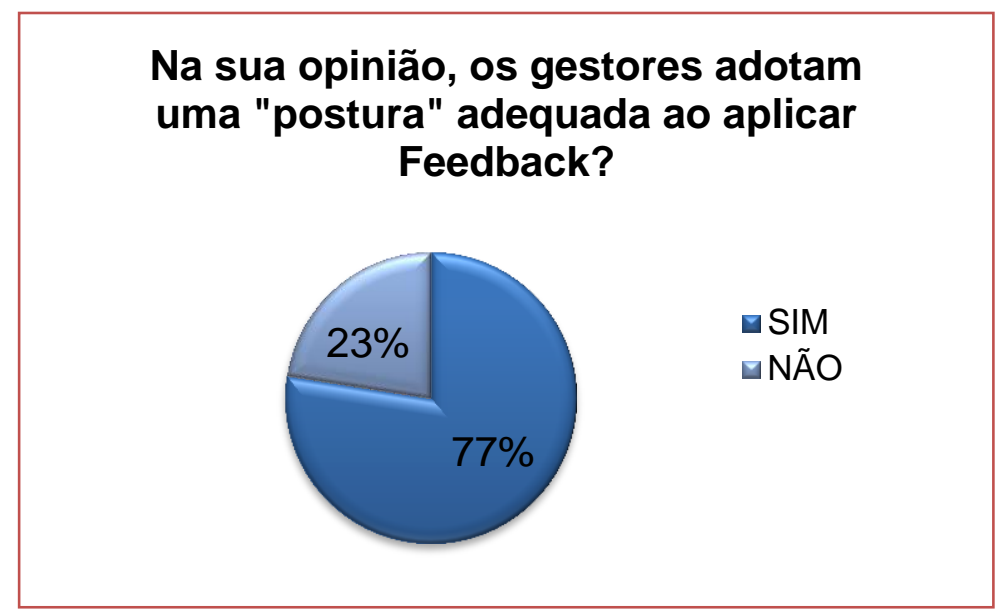

Fonte: Elaborado pela autora. 


\section{CONSIDERAÇõES FINAIS}

A partir dos conceitos teóricos utilizados dos contextos abordados, nesta pesquisa pode-se ressaltar que a Comunicação quando utilizada de maneira eficaz em todos seus departamentos e níveis hierárquicos auxilia no alcance dos interesses organizacionais e bons resultados. Tal resultado comprova-se pelo índice de $86 \%$ empregados que afirmam que o Feedback é um método assertivo e outras 50\% que não tem uma Comunicação boa em suas organizações.

Compreendendo a complexidade do cenário atual, aliada a estratégias e utilizando as ferramentas da comunicação é possível diminuir as deficiências, permitindo ao corpo gerencial desenvolver habilidade de ser bons ouvintes, tornando-os capazes de interpretar expressões, posturas, e comportamentos não verbais que afetam a motivação e rendimento dos colaboradores, a partir disso é possível entender o papel do Feedback dentro da comunicação e utilizá-lo de forma eficiente de acordo com o perfil e desempenho de cada um.

Desta forma, é possível redesenhar a forma de gestão, e a autogestão, entendendo que não é apropriado somente atender as exigências de mercado. Sendo necessário investir em formas e processos de comunicação e não exclusivamente em tecnologias e/ou treinamentos.

Sugere-se para pesquisas futuras o aprofundamento na questão da Comunicação Corporativa para que amplie-se em demais universidades já que foi realizada em somente uma Instituição da Baixada Santista, reconhecendo que tal empresa prepara seus profissionais e os alunos, envolvem-se diretamente no processo constante da Comunicação.

\section{REFERÊNCIAS}

[1] BATEMAN, Thomas S. SNELL, Scott A. Administração. 2. ed. São Paulo: Atlas, 2006.

[2] CHIAVENATO, I. Planejamento, recrutamento e seleção de pessoal: Como agregar talentos à Empresa. São Paulo: Atlas, 1999.

[3] CHIAVENATO, Idalberto. Comportamento organizacional: a dinâmica do sucesso das organizações. 2 ed. - Rio de Janeiro: Elsevier, 2005 - 3 reimpressão.

[4] GIL, A. C. Como elaborar projetos de pesquisa. 4. ed. São Paulo: Atlas, 2009.

[5] GIL, A. C. Métodos e técnicas de pesquisa social. 4. ed. São Paulo: Atlas, 1994

[6] HOHLFELDT, Antônio; MARTINO, Luiz C., FRANÇA, Vera Veiga. Teorias da comunicação: conceitos, escolas e tendências. Petrópolis: Vozes, 2001.

[7] KUNSCH, Margarida M Krohling. Planejamento de relações publicas na comunicação integrada. 4ed. rev. ampl. e atual São Paulo: Summs,2003.

[8] MERRILL, W. C.; FOX, K. A. Estatística Econômica: Uma Introdução. São Paulo: Atlas, 1977.

[9] OLIVEIRA, S. L. de. Tratado de metodologia científica: projetos de pesquisas, TGI, TCC, monografias, dissertações e teses. 1. ed. São Paulo: Pioneira, 1997. 
[10] OLIVEIRA, S. L. de. Tratado de metodologia científica: projetos de pesquisas, TGI, TCC, monografias, dissertações e teses. 2. ed. São Paulo: Pioneira, 1999.

[11] PIMENTA, M. A. Comunicação Empresarial. 3a Edição. Campinas/SP: Editora Alínea, 2002.

[12] PINHO, J. B Pinho. Comunicação nas Organizações, 1ª Ed. Editora UFV, São Paulo, 2006.

[13] ROBBINS, Stephen P. Organizational Behavior. 9th Edition. Ed Prentice Hall International, San Diego University, 2002.

[14] ROBBINS, Stephen P. PLT Comportamento Organizacional. 9 ed. São Paulo: Pearson Education, Valinhos: Anhanguera Educacional, 2007.

[15] TORQUATO, G. Cultura. Poder - Comunicação e Imagem: Fundamentos da nova empresa. São Paulo: Editora Pioneira, 2002.

[16] YIN, R. K. Estudo de caso: planejamento e métodos. 3. ed. Porto Alegre: Bookman, 2005.

[17] KUNSCH, Margarida M Krohling. Comunicação Organizacional. vol 1: Histório,fundamentos e processos. São Paulo.Ed Saraiva,2009

[18] WILLIANS, Richard L. Preciso saber de estou indo bem!. 1 ed. Rio de Janeiro: Editora Sextante,2005. 


\section{Capítulo 2}

\section{Clima Organizacional: Um diferencial estratégico na gestão da qualidade e serviços na empresa Valor}

Seguros.

\section{Elizangela Oliveira Jesus \\ Wanderson Silva Damião \\ Erick Dawson de Oliveira \\ Vitor Cezar Oliveira Neto}

Resumo: A busca por qualidade tornou-se vital para as organizações em todo o mundo. $\mathrm{Na}$ maior parte do século $\mathrm{XX}$, as organizações sofriam poucas mudanças, as quais ocorriam, geralmente, mediante necessidades importantes ou urgentes. No século XXI, com a evolução das TICs - Tecnologias da Informação e da Comunicação, as organizações passam por constante mudança para lidar com o aumento da competitividade, cumprir novas legislações, introduzir novas tecnologias e, principalmente, atender novas demandas e necessidades que surgem freqüentemente no mercado. Durante a implantação da gestão da qualidade, é importante que todos os setores e colaboradores da organização participem deste processo, gerando uma política organizacional coesa entre todos os envolvidos. Nesse contexto, a presente pesquisa realizou uma análise sobre a importância do clima organizacional como um diferencial estratégico na gestão da qualidade da prestação de serviços na empresa Valor Seguros. 0 objetivo do presente estudo está relacionado às principais características da gestão da qualidade, com ênfase ao clima organizacional e suas respectivas vantagens administrativas e comerciais para as organizações prestadoras de serviços que adotam esta importante ferramenta de gestão, destacando o seguinte questionamento: quais as principais vantagens administrativas e/ou comerciais para a organização que utiliza a gestão da qualidade? Quanto ao objetivo do presente estudo, foram avaliadas as principais vantagens em relação à gestão da qualidade para a organização prestadora de serviço, e suas principais influências administrativas e comerciais. 


\section{INTRODUÇÃo}

A gestão da qualidade tem a finalidade de beneficiar a todos os envolvidos com a organização, não somente o cliente, gerando uma cultura organizacional adequada e coerente com os valores da organização, bem como proporcionando qualidade em todos os setores. Desta maneira, torna-se essencial que toda organização planeje e aplique a gestão de qualidade, a fim de elevar o nível de qualidade e a competitividade no mercado. A necessidade de se adaptarem a essas transformações não é exclusivamente dos gestores, mas sim de todos os membros que participam ativamente do processo organizacional.

Pode-se afirmar, portanto, que os principais desafios do ambiente externo estão relacionados à economia brasileira, no contexto do tema deste estudo - gestão da qualidade. Quanto ao ambiente interno, as organizações também enfrentam diversos desafios em relação à gestão da qualidade. Para tanto, é necessário que os gestores compreendam a importância em planejar e adotar estratégias relacionados a gestão da qualidade, com o objetivo de elevar o nível de eficiência sobre todos os setores da organização.

Levando em consideração a teoria da administração, as organizações são relacionadas muitas vezes com organismos vivos, flexíveis e capazes de se adequarem aos ambientes conforme as demandas e necessidades do mercado. Assim, é possível afirmar que a gestão de pessoas pode se tornar uma importante estratégia para as organizações, dependendo da tomada de decisão dos gestores e de seus respectivos valores, planejamento, filosofia, política interna, entre outros fatores importantes que podem contribuir para a gestão da qualidade da organização.

O presente estudo trata sobre as questões relacionadas ao clima organizacional na empresa Valor Seguros, fundada em 2015 na cidade de Belo Horizonte inicialmente com a razão social BH Mais Corretora Corretora de Seguros e posteriormente, incorporada ao Grupo Valor Operações Financeiras, alterando assim, a razão social para Valor Consultoria e Corretagem de Seguros. Atualmente a operação seguros, tem sede principal em Belo Horizonte e uma filial em Santos, trabalhando todos os tipos de seguros que o mercado comercializa, paralelamente a estas duas sedes a Valor Seguros deu início a uma expansão na operação de seguros através da operação de franquias.

A fim de oferecer um estudo sobre o clima organizacional e sua importância para a gestão de qualidade quando tratada pelos gestores como uma estratégia de endomarketing, onde o foco são os colaboradores, com a finalidade de elevar o nível de qualidade em todos os setores e processos da organização e, consequentemente, elevar o nível de prestação de serviços e/ou desenvolvimento de produtos.

Diversos fatores envolvem as relações de trabalho, influenciando na satisfação dos funcionários. Dentre estes, há a subjetividade humana - interesses, valores, motivações, comunicação, história de vida, entre outros. E, dependendo da situação, a singularidade de um determinado indivíduo pode afetar o grupo de trabalho no qual está inserido, de maneira positiva, ou ainda, negativamente. Mas, afinal, o clima organizacional influencia na produtividade dos funcionários? Quais os principais pontos positivos e negativos sobre esta influência no ambiente corporativo? 
Como objetivo geral, o presente estudo tem a finalidade de apresentar as principais características relacionadas ao clima organizacional, dentro do contexto sobre a gestão da qualidade, destacando também suas vantagens para as organizações.

Em relação aos objetivos específicos desse estudo, destacam-se: análise sobre os principais conceitos referente a gestão da qualidade; levantamento dos aspectos que transformam o clima organizacional em uma estratégia competitiva aos gestores; entre outros aspectos relevantes para caracterizar e analisar o tema do presente estudo.

Os estudos, e consequentemente evolução sobre o clima organizacional nas organizações, são de extrema relevância, pois um dos grandes diferenciais das organizações é o potencial humano. Nesse contexto, é essencial que os gestores desenvolvam estratégias baseadas no clima organizacional no sentido de manter e, sempre que possível, elevar o nível de satisfação e motivação em todos os setores da organização, com a finalidade de obter o comprometimento dos envolvidos e, principalmente, extrair a máxima qualidade e potencialidade de cada indivíduo, tornando-se assim uma estratégia de endomarketing, em que o foco está nos colaboradores, oferecendo um ambiente agradável e ferramentas de qualidade para que os colaboradores, de fato, tenham condições de oferecer à organização o mesmo nível de qualidade em todos os setores da organização.

\section{APORTE TEÓRICO}

\subsection{ASPECTOS E CONCEITOS NA GESTÃO DA QUALIDADE}

Os primeiros conceitos relacionados à gestão da qualidade foram desenvolvidos na era do sistema feudal, quando, ao realizar o escambo, os senhores feudais já demonstravam uma importante preocupação sobre a qualidade do produto utilizado, agregando um valor diferenciado para os produtos que apresentassem aspectos de maior qualidade sobre outros produtos similares no mercado, segundo Longo, (1996) Já vem de muito tempo atrás a preocupação com a qualidade de bens e serviços. Os consumidores já inspecionavam os bens e serviços que selecionavam para estabelecerem uma relação de troca. Essa preocupação caracterizou a chamada era da inspeção, que se voltava para o produto acabado, não produzindo assim qualidade, apenas encontrando produtos defeituosos na razão direta da intensidade da inspeção.

Sobre a evolução histórica na área de gestão da qualidade, Longo (1996) destaca as principais eras e respectivos fatos que marcaram época na sociedade, influenciando a maneira de pensar sobre a qualidade, juntamente com as demandas do mercado, transformando a Gestão da Qualidade em um instrumento essencial das organizações públicas e privadas, não apenas visando o seu crescimento, mas, principalmente, para a sua manutenção.

A fim de desenvolver um sistema padrão para a gestão da qualidade das organizações, Garvin (1992) sugeriu quatro fases evolutivas, de acordo com a influência no desenvolvimento social e tecnológico de cada etapa, no sentido de atingir o mais alto nível de eficiência possível sobre o desenvolvimento de uma gestão da qualidade: inspeção; controle estratégico da qualidade; garantia de qualidade; gestão estratégica 
da qualidade. Embora o termo qualidade seja normalmente utilizado para significar excelência de um produto ou serviço, a qualidade de um produto ou serviço pode ser olhada por duas óticas: a do produtor e/ou prestador e a do cliente. Durante a implantação da gestão da qualidade, é importante que todos os setores e colaboradores da organização participem deste processo, gerando uma política organizacional coesa entre todos os envolvidos. Contextualiza LONGO (1996) A gestão da qualidade é um caminho importante para a reorientação gerencial das organizações. Tem como pontos básicos: foco no cliente; trabalho em equipe permeando toda a organização; decisões baseadas em fatos e dados; e a busca constante da solução de problemas e da diminuição de erros.

Segundo Coltro (1996), para que a gestão da qualidade seja implantada, é necessário haver o máximo de esforços possível por parte de toda a organização e, para tal, é necessário envolver todas as pessoas que atuam direta ou indiretamente com a organização, onde as atividades realizadas devem ocorrer por meio do estabelecimento de técnicas e ideias focadas no aumento da competitividade no mercado, visando à constante melhoria sobre os processos e, como resultado, evoluindo na melhoria (qualidade) dos produtos.

Grande parte dos autores que tratam da gestão da qualidade citam a importância de planejar e executar um conjunto de estratégias e ações, juntamente com o posicionamento dos gestores envolvidos na tomada de decisões da organização, visando à melhoria constante de todas as áreas da organização, bem como a uma evolução permanente sobre a melhoria dos produtos e/ou serviços. É essencial também que se considere o aspecto da qualidade como prioridade em todas as fases e, neste sentido, é de extrema importância que as pessoas envolvidas estejam capacitadas e adequadamente treinadas para executar suas funções com o melhor padrão de qualidade possível. As organizações precisam modernizar não só os aspectos estruturais e tecnológicos, mas também os aspectos humanos, culturais e intelectuais (GARVIN, 1992).

Para adentrar no segmento prestação de serviço, torna-se imprescindível contextualizar o termo serviços ou prestação de serviços, sendo ambos os termos, conotados como atividades que são realizadas por um indivíduo ou instituição/ organização visando atender a uma demanda, público, ou necessidade específica, seja de um outro indivíduo ou organização.

\subsection{QUALIDADE NA PRESTAÇÃO DE SERVIÇOS}

O termo serviço, ou prestação de serviços, trata da realização por um indivíduo ou uma organização visando atender a uma demanda, público, ou necessidade específica, seja de um outro indivíduo ou organização. A prestação de serviços pode estar vinculada a diferentes âmbitos, como social, industrial, ambiental, educacional, construtivo, hospitalar, administrativo, projetista, paisagístico, agropecuário ou qualquer outro, mostrando assim a necessidade das empresas fazerem o melhor possível visando serem referências em suas respectivas áreas (XAVIER, 1996; TRAVASSOS; MARTINS, 2004; COSTA, 2007).

Devido a esta multiplicidade de setores que podem ser atendidos na prestação de serviços, é importante exaltar os novos modelos de gestão que vem sendo adotados focando na qualidade dos serviços prestados 
aos clientes, as lições aprendidas no cotidiano, devem ser utilizadas para a construção de modelos e formas de ação estratégica que gere benefícios para ambas as partes, melhorando a qualidade do serviço prestado, resultado em maior número de clientes e/ou de clientes fidelizados para a empresa e resultando em um atendimento prazeroso e satisfatório para o cliente (XAVIER, 1996).

Entretanto, não basta apenas a organização investir em qualidade na prestação de serviços. Deve buscar também formas para divulgar este diferencial empresarial, visando a atração de novos prospects, seja por comentários de outros clientes, ou por especulações geradas por uma postura diferenciada no mercado. Criando tal abordagem, torna-se evidente a necessidade da utilização do marketing empresarial. A organização deve realizar serviços com qualidade, buscando estratégias competitivas para seu segmento e, dentre estas estratégias, o marketing merece destaque como forma de construir a marca, além de atrair e fidelizar clientes potenciais, possibilitando assim, o conhecimento da forma de atuação da organização de maneira ampla e consistente (ISECENSA, 2017).

Retomando o foco para as medidas de qualidade em prestação de serviços e as vantagens estratégicas que tal abordagem fornece as empresas, torna-se necessário fazer menções históricas, relatando que desde 1980 ou antes, já buscava-se a chamada excelência em serviços, de forma que a qualidade era um indicativo de tal atribuição, a mensuração da excelência por meio da qualidade, vêm crescendo nos últimos anos, e caracteriza-se como uma estratégia para obtenção de maiores vantagens competitivas, sendo muito diversificada a literatura, relatando diversos aspectos específicos para certos segmentos, e ao menos tempo amplos para diversos contextos, assim a qualidade em serviços não apresenta um padrão ideal, ela pode ser composta de medidas extremamente afuniladas para um contexto e muito expansivas em outro (FREITAS, 2005).

Muitos estudos foram realizados antes de Silva (1997), e muitos outros posteriormente e hoje sabe-se que como enfatizado por Freitas (2005), a qualidade não é uma abordagem estática e engessada para as empresas seguirem um modelo, mas se trata de um conceito dinâmico e modelável a cada contexto em que é aplicada.

Vários autores tem se dedicado a compreender e transmitir sua compreensão sobre o conceito de qualidade em serviços, visando sua utilização como forma de mensurar a eficácia e eficiência destes serviços, dentre tais instrumentos citados para tal utilização do conceito com vistas a melhoria do contexto empresarial, pode-se destacar a auto-avaliação, gerando mudanças na forma e apresentação dos serviços, dentre meios facilitadores para atingir a qualidade e excelência em serviços, é possível fazer menção a aplicação de modelos de excelência como o EFQM - European Foundation for Quality Management e CAF - Common Assessement Framework, entre outros (LOURO, 2009).

A seguir será abordado o tema Clima Organizacional que pode ser entendido como as impressões gerais ou as percepções dos colaboradores sobre a organização e seu ambiente. 


\subsection{CLIMA ORGANIZACIONAL, CULTURA E PRODUTIVIDADE}

Um dos principais problemas envolvendo o ambiente externo das empresas, bem como dos trabalhadores em todos os ramos de atividade, é a economia brasileira. Com base em números divulgados pelo IBGE (2016), o Brasil tem cerca de 12 milhões de desempregados. A taxa de desemprego cresceu 3,8\%. No período de apenas 12 meses, são 3 milhões a mais de pessoas sem uma ocupação remunerada no Brasil. 0 número de empregos formais no setor privado, ou seja, com carteira assinada, também apresentou queda de $0,9 \%$, somando 34,1 milhões de profissionais. Na comparação com o terceiro trimestre/2016, houve queda de $0,9 \%$, o que representa 314 mil pessoas sem registro em carteira no período. Na comparação anual, a queda no número de empregos formais foi de 3,7\% (IBGE, 2016).

De acordo com Chiavenato (2010), a instabilidade do mercado de trabalho no Brasil, infelizmente, é alta. As pessoas que encontram-se em estado de desemprego enfrentam grandes dificuldades no processo de recolocação ao mercado de trabalho. Devido à grande taxa de desemprego no Brasil, muitos funcionários que estão empregados passam por instabilidade emocional devido ao receio de perder seu emprego, fazendo com que o IMD - Índice de Medo do Desemprego, mensurado pela Confederação Nacional da Indústria (CNI, 2017), apresentasse alta ao somar 3,6 pontos em dezembro/2016, ao atingir 64,8 pontos. $\mathrm{O}$ indicador terminou o ano de 2016 acima da média histórica de 48,4 pontos. Vale ressaltar que o indicador varia de zero a 100 pontos e que por isso, quanto mais elevado estiver, maior é o medo do desemprego. Pode-se afirmar, portanto, que os principais desafios do ambiente externo estão relacionados à economia brasileira, no contexto dos temas deste estudo - clima organizacional e produtividade. Devido à sensação de insegurança econômica no Brasil, torna-se extremamente difícil, atualmente, manter o equilíbrio e o controle emocional aliados à perspectiva profissional, num país onde é visível a dificuldade para ocupação de um lugar no mercado de trabalho e onde as pessoas acabam candidatando-se a vagas, sobretudo por necessidades financeiras e não pessoais.

Há também os desafios relacionados ao ambiente interno das empresas, relacionados ao clima organizacional, os quais devem ser devidamente conceituados e analisados, com o objetivo de extrair elementos para investigação, bem como gerar resultados para tomada de decisões pelos gestores e analistas das organizações. O clima organizacional tem, dentre as suas principais finalidades, a compreensão das necessidades, preocupações e percepções dos colaboradores nas organizações. A literatura mostra diversas definições para esse termo, tais como: apoio organizacional percebido (EISENBERG; HUNTINGTON; HUNTINGTON; SOWA, 1986); estrutura da organização (PAYNE; PUGH, 1976); grau de similaridade entre as expectativas da organização e as dos empregados (GLICK, 1985).

Diante de um mercado cada vez mais competitivo, o fator humano é um diferencial importante na concorrência entre as empresas. Compreender e valorizar os colaboradores é uma medida inteligente por parte dos gestores e analistas que desejam obter melhoria e vantagem competitiva no mercado (CAMPELLO; OLIVEIRA, 2008).

Segundo Chiavenato (1992), clima organizacional é o ambiente humano no qual as pessoas de uma organização fazem o seu trabalho. Constitui a qualidade ou propriedade do ambiente organizacional, percebida ou experimentada pelos envolvidos na empresa, influenciando o seu comportamento. 0 autor, 
em outra obra, resume as principais consequências - pontos positivos e negativos - geradas em um clima organizacional, de acordo com as percepções das pessoas envolvidas no ambiente de trabalho. Contextualiza CHIAVENATO (2010) 0 clima organizacional é favorável quando proporciona satisfação das necessidades pessoais dos participantes, produzindo elevação do moral interno. É desfavorável quando proporciona frustração daquelas necessidades.

As pessoas são fonte criadora e fundamental no processo de construção, desenvolvimento e crescimento organizacional. Uma organização para ser eficaz e auto renovável, precisa de funcionários que queiram ampliar as suas experiências e que possam aumentar as suas contribuições. 0 melhor clima para que isso aconteça, é aquele que cria oportunidade para crescimento, dando ênfase à colaboração, comunicações abertas, confiança interpessoal, divisão de poder e confrontação construtiva (DAVIS, 1992).

\subsection{ESTUDO DE CASO}

A empresa Valor Seguros, que tem como missão consolidar-se como uma referência em prestação de serviço no ramo de corretagem de seguros, com sede principal localizada em Belo Horizonte - MG e com filial em Santos - SP define como sua maior preocupação resultados satisfatórios na qualidade da prestação de serviço atendendo os clientes de forma inovadora com aspecto diferenciado em excelência e paralelamente desenvolvendo seus colaboradores de forma que se sintam valorizados, respeitados e realizados profissionalmente, tranzendo bons resultados individualmente e coletivamente.

\section{METODOLOGIA}

Partindo do pressuposto que a organização em estudo possuía pouco conhecimento acumulado sobre o tema proposto, optou-se pela pesquisa exploratória. Pesquisa exploratória é recomendada a áreas em que existe pouco conhecimento prévio daquilo que se pretende conseguir (VERGARA 2000). MALHOTRA (2001) acrescenta que a pesquisa exploratória é um tipo de pesquisa que tem como principal objetivo o fornecimento de critérios sobre a situação-problema enfrentada pelo pesquisador e sua compreensão, ou seja, o pesquisador é abastecido de dados e informações que processados facilitam a compreensão e consequentemente, a solução da questão do estudo. Trata-se, portanto, de uma pesquisa exploratória, pois o mesmo foi desenvolvido numa corretora de seguros em Belo Horizonte-MG e Santos-SP, que possuía pouco conhecimento sobre o nível de satisfação de seus clientes pelo fato de ter pouco tempo de experiência com o público cliente.

A abordagem do problema foi feita de forma qualitativa quando da elaboração dos processos de melhoria e também quando da análise, visando a melhor maneira de aumentar o nível de satisfação dos clientes.

\section{ANÁLISE E DISCUSSÃO DOS RESULTADOS}

0 presente projeto direcionado aos seus clientes e colaboradores obteve resultados satisfatórios em alguns pontos, como, a melhoria na Comunicação da empresa através da implantação de um chat 
corporativo no qual os funcionários das duas sedes, Belo Horizonte e Santos, passaram e se comunicar com mais clareza e rapidez reduzindo significativamente ruídos na comunicação e retorno com mais rapidez aos clientes, foi implantado também um método de avaliação 360ํaonde colaboradores e gestores se avaliam mutuamente e posteriormente se reúnem para discutir os pontos positivos e negativos abordados nas avaliações. No âmbito externo foi criado um setor para realizar pesquisa de avaliação dos clientes a fim de coletar informações de pontos positivos e negativos. 0 entrevistado 1 salientou que, "o processo de renovação do seguro este ano foi mais rápido e prático o consultor foi mais claro nas informações do meu contrato de renovação", já o entrevistado 2 afirma, "não notei tanta diferença no atendimento, mas de qualquer forma estou satisfeito com o processo da empresa, sempre me atendendo dentro das expectativas".

Diante dos resultados apontados na pesquisa é possível notar uma melhoria satisfatória no clima organizacional interno e uma maior satisfação do cliente. As organizações públicas e privadas enfrentam diversos desafios relacionados ao ambiente interno e externo. Nesse sentido, o presente estudo destaca o clima organizacional como uma importante estratégia aos gestores, a fim de gerar resultados para tomada de decisões pelos gestores e analistas das organizações.

\section{CONSIDERAÇÕES FINAIS}

O clima organizacional é de grande importância para melhorar o ambiente de trabalho nas empresas, em todos os ramos de atividade. Análise e avaliação de relacionamento em todos os setores, conduta dos envolvidos, relação entre colaboradores e diretoria, e assim por diante. De uma maneira geral, uma das principais características do clima organizacional é o potencial de melhorar o convívio entre as pessoas e os setores de uma organização. Por meio da melhoria do ambiente de trabalho, as organizações criam condições de organizar, qualificar e ampliar a produtividade e oferta de produtos e serviços no mercado.

Acima de equipamentos e insumos, as empresas precisam de capacidade humana, ou seja, explorando o que há de melhor em cada indivíduo, para alcançar seus objetivos e aplicar seus recursos. As empresas precisam de colaboradores satisfeitos, motivados, capazes de utilizar todo o seu potencial em benefício da empresa, visando ao crescimento mútuo.

Um clima organizacional negativo gera apatia, rotatividade de funcionários, frustração e insatisfação dos colaboradores, conflitos de relacionamento, levando a maioria dos funcionários à condição de desmotivação e baixa autoestima. Desta maneira, os resultados oferecidos por estes funcionários também são negativos, gerando uma série de problemas para a empresa. A ausência de uma devida atenção sobre o clima organizacional pode, inclusive, impedir que avanços maiores ocorram em assuntos relacionados à gestão estratégica, plano estratégico, planejamento de marketing e assim por diante. A empresa é feita por pessoas, acima de tudo. E, como tal, é de extrema importância que as empresas cuidem das pessoas, evitando colocar em risco os objetivos mercadológicos e o futuro das organizações.

Diversos conflitos ocorrem em muitas organizações, cujo problema afeta de forma direta o clima organizacional das organizações. A comunicação ineficiente entre colaboradores, líderes e gestores, bem 
como atitudes negativas, ausência de estabilidade emocional e falta de harmonia profissional entre os envolvidos comprometem os resultados de uma organização, principalmente, no aspecto da produtividade de produtos e/ou serviços, bem como na produtivdade de processos e sistema da organização de um modo geral.

Nesse contexto, o presente estudo analisou e destacou alternativas e sugestões por meio do clima organizacional, embasados em importantes autores da área. Assim, os gestores tem a possibilidade de buscar e incentivar a produtividade por meio de inovações, criatividade e desenvolvimento de táticas de acordo com demanda e/ou necessidade em todos os setores da organização, com a finalidade de diminuir o estresse dos colaboradores e seus respectivos líderes, bem como ampliar a qualidade da comunicação, dos processos, dos produtos e/ou serviços e do sistema em geral da organização, por meio de colaboradores cada vez mais motivados a enfrentar os desafios que o mercado impõe para as organizações.

Conclui-se, portanto, que o clima organizacional é, de fato, um diferencial estratégico na gestão da qualidade das organizações, pois é uma das maneiras mais eficazes para diminuir o turnover (percentual de rotatividade de colaboradores dentro de uma organização), criar uma harmonia entre a cultura organizacional e as atividades da organização, integrar vários processos e setores funcionais, melhorar a comunicação entre os envolvidos, filtrar demandas e necessidades de capacitação para os colaboradores, otimizar as atividades gerenciais no sentido de torná-las mais resistentes, oferecer um ambiente profissional cada vez mais estável e harmonioso para os envolvidos desenvolverem suas atividades com mais concentração e eficiência, dentre outros inúmeros benefícios que proporcionam resultados positivos para a organização - crescimento e estabilidade dos colaboradores no ambiente interno e também no ambiente externo da organização, maior competitividade por meio de produtos e serviços realizados com maior qualidade, entre outros.

Uma organização que dispõe de um ambiente de trabalho favorável, onde há uma predisposição dos envolvidos a manterem um clima de colaboração, comprometimento e relações saudáveis, gera satisfação sobre as necessidades e demandas das pessoas, promovendo imensamente a sua motivação com o trabalho. Assim, as atitudes destes colaboradores também se tornam positivas para as organizações, por meio do aumento de produtividade, criatividade e capacidade de adaptarem-se a eventuais mudanças, gerando motivação nas atividades que excercitam e, consequentemente, bons resultados a todos.

\section{REFERÊNCIAS}

[1] CAMPELLO, Mauro; OLIVEIRA, Juliana Sevilha Gonçalves de. Clima Organizacional e o Desempenho das Empresas. In: XIII SIMPEP - Simpoósio de Engenharia de Produção, 6 a 8 de novembro. Bauru, 2006. Disponível em: <http://www.simpep.feb.unesp.br/anais/anais_13/artigos/413.pdf>. Acesso em: 24 nov. 2017.

[2] CHIAVENATO, Idalberto. Comportamento Organizacional: A Dinâmica do Sucesso das Organizações. 2. ed. Rio de Janeiro: Elsevier, 2010.

[3] CNI - Confederação Nacional da Indústria. Medo do Desemprego Sobe e Alcança Segunda Maior Marca da Série Histórica, Informa CNI. CNI/Agência de Notícias. Artigo publicado em 6 de outubro de 2017. Disponível em: 
<http://www.portaldaindustria.com.br/agenciacni/noticias/2017/10/medo-do-desemprego-sobe-e-alcancasegunda-maior-marca-da-serie-historica-informa-cni/>. Acesso em: 24 nov. 2017.

[4] COLTRO, Alex. A Gestão da Qualidade Total e Suas Influências na Competitividade Empresarial. v. 1 , n. 2, 7 p.

São Paulo: Cadernos de Pesquisa em Administração, 1996. Disponível em:
<https://www.google.com.br/url?sa=t\&rct=j\&q=\&esrc=s\&source=web\&cd=3\&ved=0ahUKEwiiyrzSj9jXAhWEIZAKHU kBYQQFgg7MAI\&url=http\%3A\%2F\%2Fxa.yimg.com\%2Fkq\%2Fgroups\%2F20980813\%2F687382980\%2Fname\%2F C02-art04_qualid_compet_COLTRO.pdf\&usg=AOvVaw0xgAPns-vjoxbl8wyXqZ9Q>. Acesso em: 24 nov. 2017.

[5] COSTA, Eliezer Arantes da. Gestão Estratégica: Da Empresa que Temos para a Empresa que Queremos. 2. ed., 424 p. ISBN: 978-85-02-06188-0. Saraiva, 2007.

[6] DANTAS, S. Gestão Estratégica de Negócios. Encontros Cooperativos - Seguros Unimed, 2011.

[7] GARVIN, David A. Gerenciando a Qualidade: A Visão Estratégica e Competitiva. 357 p. Rio de Janeiro: Qualitymark, 1992.

[8] IBGE - INSTITUTO BRASILEIRO DE GEOGRAFIA E ESTATÍSTICA. Brasil tem 12 Milhões de Desempregados, Aponta IBGE. Artigo publicado em 27 de outubro de 2016, pelo portal IG - Economia. Disponível em: <http://economia.ig.com.br/2016-10-27/desemprego.html>. Acesso em: 24 nov. 2017.

[9] ISECENSA - Institutos Superiores de Ensino e do Centro Educacional Nossa Senhora Auxiliadora. Marketing de Serviço. Instituto de Ciências Sociais Aplicadas, 2017.

[10] LONGO, Rose Mary Juliano. Gestão da Qualidade: Evolução Histórica, Conceitos Básicos e Aplicação na Educação. Texto para Discussão no 397, 16 p., jan. IPEA - Instituto de Pesquisa Econômica Aplicada, 1996. Disponível em: <http://desafios2.ipea.gov.br/agencia/images/stories/PDFs/TDs/td_0397.pdf>. Acesso em: 24 nov. 2017.

[11] PAYNE, R. D.; PUGH, D. S. Organizational Structure and Climate. In: Handbook of Industrial Organizational Psychology. p. 1125-1173. Rand McNally, 1976.

[12] SILVA, S. C. Elementos Fundamentais Para a Excelência na Prestação de Serviços. Porto Alegre: UFRGS Universidade Federal do Rio Grande do Sul, 1997.

[13] TRAVASSOS, Claudia; MARTINS, Mônica. Uma Revisão Sobre os Conceitos de Acesso e Utilização de Serviços de Saúde. v. 20, suppl. 2. DOI: 10.1590/S0102-311X2004000800014. On-line version ISSN: 1678-4464. Rio de Janeiro: Cadernos de Saúde Pública, 2004. Disponível em: <http://www.scielo.br/scielo.php?script=sci_arttext\&pid=S0102311X2004000800014>. Acesso em: 24 nov. 2017.

[14] XAVIER, Antonio Carlos da R. A Gestão de Qualidade e a Excelência dos Serviços Educacionais: Custos e Benefícios de Sua Implantação. Texto para Discussão no 408. mar. Brasília: IPEA - Instituto de Pesquisa Econômica Aplicada, 1996. Disponível em: <http://www.ipea.gov.br/agencia/images/stories/PDFs/TDs/td_0408.pdf>. Acesso em: 24 nov. 2017. 


\section{Capítulo 3}

o uso da tecnologia da informação no processo de construção da aprendizagem: Um estudo de caso da percepção de docentes universitários

\section{Elizangela Oliveira Jesus \\ Wanderson Silva Damião \\ Erick Dawson de Oliveira \\ Shusther Azevedo Almeida}

Resumo: 0 objetivo deste trabalho é identificar o impacto e as consequências do uso da tecnologia da informação no universo educacional de uma instituição de ensino superior (IES), considerando a percepção de docentes universitários. Foram aplicados 35 questionários aos docentes universitários de uma IES, buscando uma coleta de dados de natureza quantitativa, com o propósito de se ter um resultado claro e objetivo. Espera-se que este trabalho possa contribuir como suporte para um melhor entendimento das questões que permeiam o uso da tecnologia da informação no universo educacional, com foco nos docentes universitários e que contribua para futuras pesquisas. Este texto está dividido em cinco partes: na primeira apresenta-se um pequeno histórico do uso da tecnologia na sociedade, na segunda parte, são apresentados conceitos de diversos autores relativos a tecnologia e seu uso na educação. Já na terceira parte, apresenta-se a metodologia utilizada no decorrer do trabalho. Por fim, são discutidos os resultados obtidos através das ferramentas e técnicas metodológicas. 


\section{INTRODUÇÃo}

Quando se discute sobre tecnologia quase sempre associa-se este termo a informática ou a robótica, mas não se limita a estas duas áreas, a tecnologia pode ser aplicada em diversas situações.

A palavra tecnologia tem origem grega, sendo resultado da junção do termo tecno, do grego techné, que é saber fazer, e o termo logia, do grego logus, razão, assim podemos dizer que tecnologia é o estudo das técnicas e de todo seu conhecimento, com o objetivo de satisfazer as necessidades dos seres humanos, a partir da busca da "razão do saber fazer", aprendendo e dominando técnicas que resultarão na criação ou modificação de ferramentas que facilitem a vida das pessoas ou satisfaçam suas necessidades e desejos.

Na idade da pedra a tecnologia já era utilizada, os homens das cavernas precisavam se defender e também coletar alimentos, com isso eles acabaram criando ferramentas que os auxiliavam nestas atividades (RODRIGUES, 2001).

Atualmente estamos cercados de produtos e ferramentas frutos da tecnologia, um grande exemplo são os celulares, antigamente era um objeto de luxo que poucas pessoas tinham acesso, hoje em dia as pessoas já o tratam como um objeto de necessidade no seu dia a dia. Também pode-se citar a transformação que acontece no mercado, cada vez mais as organizações estão buscando tecnologias que produzam mais e custem menos, fazendo com que seus processos se tornem totalmente automatizados, consequentemente as pessoas são substituídas por estes sistemas.

É perceptível a extinção de cargos, as pessoas acreditam que apenas cargos com atividades repetitivas estariam ameaçados, mas não é bem assim, o pesquisador Carl Frey, da Universidade de Oxford, elaborou uma metodologia que estima as chances de um emprego ser automatizado, Carl afirmou em uma entrevista a BBC Brasil: "Nenhuma indústria ou ocupação é imune à automação. No passado, isso estava restrito a atividades repetitivas. Agora, há um imenso volume de dados sendo gerados. A tecnologia de computação se sofisticou. Equipamentos eletrônicos usados na robótica estão melhores e mais baratos".

Observa-se que no âmbito universitário o que vem se destacando cada vez mais é o ensino a distância ou EAD, uma modalidade de ensino aonde os alunos e professores não precisam estar presentes em um ambiente presencial. De acordo com o portal online EAD (2017), o registro mais antigo desta modalidade foi na cidade Boston, nos Estados Unidos, no ano de 1728, era um curso de Taquigrafia uma técnica para escrever á mão de forma rápida, usando códigos e abreviações, era oferecido por um professor chamado Caleb Phillips, o curso na época era anunciado no jornal e os interessados que contratassem este serviço recebiam o material semanalmente pelo correio.

Segundo o porta online EAD (2017), no Brasil o registro mais antigo de curso na modalidade em ead é de 1904, no caso um curso de datilografia foi totalmente por correspondência. Em 1920 já existiam no Brasil os cursos que eram transmitidos por rádio, a novidade tecnológica daquela época, as pessoas utilizavam o contéudo impresso para aprender sobre temas relacionadas á radiodifusão, Francês e Português. Entre 1960 e 1970 surgiram várias iniciativas de ead, que tinha como objetivo de fomentar a inclusão social de adultos e ampliar o acesso à educação. E no final da década de 1970, em Brasília, foi iniciada a primeira experiência em ead no ensino superior. 
Na próxima seção é apresentado o referencial teórico, expondo alguns conceitos de diversos autores, relativos a tecnologia e seu uso na educação.

\section{APORTE TEÓRICO}

0 capitulo a seguir está dividido em três tópicos, da seguinte forma: A tecnologia no século 21, tecnologia na educação e papel do professor frente as novas tecnologias.

\subsection{A TECNOLOGIA NO SÉCULO 21}

Um dos principais motivos para evolução do ser humano foi o avanço tecnológico. 0 homem na idade da pedra já fazia uso da tecnologia, dominando o fogo e criando ferramentas, mas o grande marco na evolução do ser humano foi o desenvolvimento da comunicação, onde iniciou-se a transmissão do conhecimento. Mas o salto que houve nas últimas décadas foi enorme, hoje em dia já é possível clonar seres vivos, como por exemplo, a ovelha Dolly, que foi clonada a partir de uma célula adulta, também já existem robôs ou softwares que substituem o trabalho dos seres humanos em certas áreas. Com tudo isso se tornou um desafio, se adaptar a essa nova era chamada de era da informação, onde o capital intelectual é mais valorizado (ZUFFO, 2002).

Antigamente o que limitava o ser humano a evoluir era a escassez de informações, mas hoje é o contrário, como relata Lima (2001), "Hoje, um dos maiores problemas com que nós defrontamos no meio ambiente já não é a falta de informação, mas sim a seleção adequada ou filtragem daquela que pode nós ser efetivamente útil.". Com base no pensamento do autor é possível entender qual é a dificuldade do ser humano para se adaptar, a cada dia que se passa o mundo virtual se torna mais presente, podendo-se dizer que a internet é o fio condutor e é nela que está presente o maior amontoado de informações, além de transformar as pessoas em criadoras de novos conhecimentos e não só receptoras, essa mudança é chamada de "Estado Digital", onde o espaço físico será substituído pelo virtual e com isso serão criadas novas relações econômicas, culturais e sociais entre os indivíduos e o meio ambiente, essa transição já é perceptível, a presença das pessoas já é maior no mundo digital do que no real, como por exemplo nas redes sociais (MARTIN,1997). Mas o grande problema como relatado anteriormente é a filtragem das informações, a cada momento novas informações são geradas, podendo ser elas úteis ou não, o papel das pessoas é entender as novas demandas impostas pelo avanço tecnológico, colocando como prioridade a educação, como afirma o autor Lima (2000), "Temos que colocar a educação, em todas as suas modalidades de manifestação, como prioridade básica de nossas vidas, transformando nosso existir em um processo dialético de educação permanente."

Com isso pode-se dizer que as pessoas precisarão ser mais atuantes na busca do conhecimento com base nas novas tendências, sendo necessária uma transformação no método de aprendizagem, buscando focar no "aprender a pensar" e não no "aprender a fazer", o papel da educação não será mais de "enlatar" o conhecimento para transmiti-lo, o seu objetivo será de ensinar as pessoas a filtrar a relevância das informações, além de ensinar cada indivíduo a desenhar seu programa de autoeducação, com base nas 
suas necessidades. As pessoas precisarão buscar novos caminhos, pois em uma sociedade que se altera diariamente a busca por aperfeiçoamento e novos conhecimentos não é mais uma escolha pessoal e sim uma necessidade básica, para sobreviver (LIMA, 2000).

Com todo esse avanço a nova geração já nasceu no meio da tecnologia e tem disponível um número abundante de informações, como Tapscott (1999) diz, "pela primeira vez na história, as crianças sentemse mais confortáveis, são mais instruídas e versadas que seus pais numa inovação tão importante para a sociedade", não é difícil ver crianças que mal saíram das fraldas e já sabem mexer em um smartphone ou tablet, enquanto a uma certa resistência ou dificuldade da geração passada por usar estes produtos frutos da tecnologia. Mas como consequência essa nova geração fica exposta a tudo que está presente na internet, podendo ser benéfico ou não, indo desde conteúdo educacional, até indivíduos mal-intencionados (TAPSCOTT, 1999).

É necessária uma fiscalização e identificação dos reais perigos ao que essa geração está exposta, é preciso ser tomada alguma ação para evitar que ela seja impactada negativamente, mas ao mesmo tempo evitar ações radicais, como por exemplo, negar o uso destas novas tecnologias, pois iriamos contra a evolução humana estaríamos negando todo o trabalho e conhecimento que foram desenvolvidos por nossos antepassados durante os séculos.

Na próxima seção discute-se a tecnologia no ambiente educacional.

\subsection{TECNOLOGIA NA EDUCAÇÃO}

Atualmente ainda se faz o uso das "velhas tecnologias" dentro das salas de aula, sendo representadas principalmente por materiais impressos e lousa escolar, que acabam impondo certos limites na prática da transmissão do conhecimento.

A globalização impactou diretamente a educação, surgiu a imprescindibilidade de se adaptar as novas demandas, a principal necessidade é a de formar profissionais focados para a sua realidade e capacitados a solucionar adversidades de forma criativa. Para que isso seja possível é preciso utilizar-se de ferramentas mais flexíveis, que melhorem os métodos de pesquisas e comunicação, com isso diminuindo o uso de conteúdo fixo e aumentando a criação de novos conhecimentos. Também será preciso reexaminar os métodos que avaliam a qualidade da educação atualmente, dentre os vários indicadores usados para mensurar o nível da educação nas instituições, o mais facilmente observável é o desempenho de seus discentes em exames nacionais, aonde muitas das vezes as instituições se utilizam do bom desempenho de seus alunos em publicidades para atrair a atenção do mercado. 0 grande problema é que desta forma a qualidade em questão se limita apenas em pressupostos técnicos, deixando de lado os interesses dos sujeitos que a definem e a adotam. A qualidade é algo a ser construído, ela está em constante transformação, a sua definição dependerá do contexto em que ela está inserida e da percepção de cada um. Resumidamente a qualidade se baseia em um arbitrário sociocultural e é norteada por reivindicações distintas e mutáveis (FRANCO, 1992). 
Um grande aliado que se enquadra em todas estes quesitos é a internet, que propicia a uma vasta escala de pessoas a disponibilidade da informação, mas mesmo com este grande potencial educativo é raro o seu uso em salas de aula, pois ainda existe uma certa negação nas vantagens educativas que essa nova ferramenta pode trazer, geralmente acaba sendo tratada como distração (JOLY e SILVEIRA, 2002).

Como foi citado por Lima (2000), precisará ocorrer mudanças na educação, onde será necessário mudar a visão de "aprender a fazer" para a "aprender a aprender". Graças aos avanços tecnológicos, principalmente a internet, as pessoas tem uma maior facilidade de acesso as informações, qualquer pessoa que tenha acesso a internet tem um mundo de informações disponíveis para si. Com toda essa facilidade de acesso as informações e as novas ferramentas precisarão ocorrer mudanças na educação, às pessoas já tem o acesso, mas não tem a expertise de filtrar as informações que são relevantes e de como transformar a informação em conhecimento, podemos fazer uma analogia com um quebra cabeça, a informação são as peças e para se transformar em conhecimento é necessário unir as peças com seus pares corretos até montá-lo, para isso é preciso o auxílio de uma pessoa que já tenha experiência no assunto (TAPSCOTT, 2010).

Com o uso de novas tecnologias acaba sendo necessário uma nova postura dos docentes, que será discutida na próxima seção.

\subsection{PAPEL DO PROFESSOR FRENTE AS NOVAS TECNOLOGIAS}

A cada dia o uso da tecnologia se torna mais notável dentro das salas de aula, trazendo consigo novas experiências e possibilidades, o papel do professor neste contexto será de desencadear transformações significativas no processo da criação do conhecimento e de seu compartilhamento, além de minimizar o impacto da lacuna das práticas acadêmicas e as demais práticas sociais, que irão aparecer ao decorrer do uso dessas novas ferramentas, tornando mais agradável e próspera a adaptação de seus discentes (BARRETO, 2002). Com isso os docentes terão um grande desafio pela frente, eles precisarão reinventar o método de aprendizagem, criando uma verdadeira revolução na educação.

Um dos principais desafios será o de substituir ou adaptar os processos que ao passar do tempo se tornaram repetitivos e padronizados. Seguindo a linha de raciocínio de Lévy $(1993,1999)$ ele defini a informática como um processo tecnológico intelectual que concebe uma nova perspectiva do mundo. Para Ramal (2002) com o avanço da tecnologia irá ocorrer grandes mudanças na educação, ele propôs três cenários. 0 primeiro é o tecnocracia domesticadora, neste cenário as pessoas se tornam escravas da tecnologia, por causa da abundância de informações irrelevantes e fracionadas. Novas modalidades de ensino substituem a escola. Já o segundo cenário é chamado de pay-per-learn, neste caso são priorizados os professores por sua habilidades técnicas e não por sua capacidade crítica de produção ou por suas habilidades no uso da tecnologia da informação e comunicação. Neste contexto a educação alcança a todos, pelo meio da internet, mas ainda existe a diferença social, aonde alunos privilegiados irão frequentar escolas melhor equipadas. No terceiro e último cenário que foi intitulado de cibereducação integradora, a educação se torna híbrida, nela há tanto presença da tecnologia quanto a do homem. 
Com este avanço tecnológico um grande problema presente na sociedade é evidenciado, a desigualdade presente nas classes sociais, os alunos que vierem da educação pública para o âmbito acadêmico, na sua grande maioria dificilmente terão o mesmo conhecimento e contato com as novas tecnologias, comparado a alunos que vierem de escolas particulares, pois as chances destes terem o acesso a tecnologia na sua vida escolar é maior, as escolas particulares são bem mais equipadas, consequência da necessidade de se tornar competitiva perante seus concorrentes, diferente das escolas públicas, que são geridas pelo governo. 0 papel do professor será essencial na adaptação destes alunos carentes de conhecimento sobre o uso e a aplicação das ferramentas tecnológicas, presentes na academia, será necessário buscar formas de igualar o conhecimento dos alunos, de forma ética e justa para não prejudicar nenhuma das partes envolvidas (MAZZOTTI, 2006).

Na próxima seção será descrita a metodologia usada na elaboração da pesquisa empírica.

\section{METODOLOGIA}

O estudo em questão se classifica como estudo de caso, que para Gil (2008) aplica-se um profundo estudo dos objetos, de forma que haja o detalhamento amplo de seu conhecimento.

A abordagem que melhor se adequa ao presente artigo é a pesquisa quantitativa, com o apoio da pesquisa descritiva. Segundo Fonseca (2002), na pesquisa quantitativa seus resultados podem ser quantificados, recorrendo à linguagem matemática para descrever as causas do problema em questão. Neste tipo de pesquisa considera que a realidade só pode ser assimilada através da análise de dados brutos, selecionados com a ajuda de instrumentos padronizados e neutros. Resumidamente, a pesquisa quantitativa foca na objetividade. A pesquisa descritiva de acordo com Gil (2008) tem por objetivo descrever as características do universo pesquisado, seu diferencial está no uso de seus técnicas de coleta de dados, como por exemplo, a observação sistemática.

Para a coleta de dados foi utilizado questionários, distribuídos entre os docentes universitários, buscando uma tabulação mais rápida e objetiva. Para Gil (1999) o questionário é uma técnica de investigação por escrito, com o foco em conhecer as opiniões, interesses, sentimentos, experiências, etc. Para a aplicação da coleta de dados foram distribuídos 35 questionários entre docentes universitários de uma IES, com o objetivo de compreender o universo da pesquisa com foco no objetivo da pesquisa, obteve-se o retorno de 20 questionários.

O tipo de amostragem utilizado foi a probabilística aleatória, com a utilização do universo docente de uma universidade, onde qualquer elemento do universo em questão tem uma chance aleatória de ser escolhido como elemento da amostra (MATTAR, 2001). Sua vantagem em comparação aos outros tipos de amostragem é a possibilidade de compensar erros amostrais entre outros aspectos que possuem grande significado e representatividade nas amostras (MARCONI e LAKATOS, 2002.). 
Figura 1 - Diagrama da metodologia utilizada deste trabalho

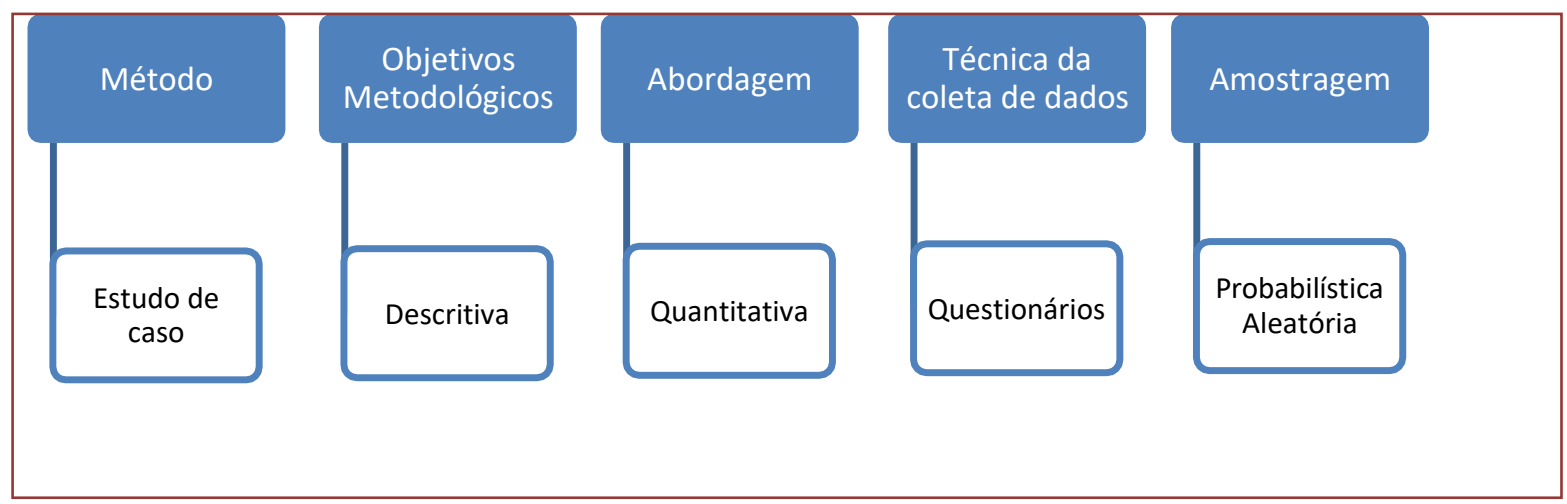

Fonte: Elaborado pelo autor a partir dos autores citados

Conforme a figura 1, pode-se observar a metodologia usada no trabalho, de forma mais simples e objetiva. Em sequência na próxima seção serão demonstrados, analisados e discutidos os resultados obtidos a partir das ferramentas e métodos citados na metodologia.

\section{APRESENTAÇÃO E DISCUSSÃO DOS RESULTADOS}

Como citado na metodologia, para a coleta de dados foram utilizados questionários, de 35 questionários que foram distribuídos entre docente universitários de diversos cursos, para se ter uma amostragem mais abrangente deste universo, houve a devolução de 20, que foram organizados e tabulados, a partir da tabulação foram elaborados gráficos com o objetivo de tornar a análise mais prática, além de tornar a experiência de leitura do artigo mais simples e objetiva.

Na próxima seção serão declarados os resultados obtidos a partir da coleta de dados, de acordo com Cordeiro (1999), a declaração dos resultados envolve os valores numéricos apresentados por gráficos ou tabelas, os resultados devem oferecer o máximo de esclarecimentos, de forma objetiva e clara, gastando o mínimo de tempo e espaço necessário. 


\section{1 - TABULAÇÃO DOS DADOS}

Gráfico 1 - Pergunta 1

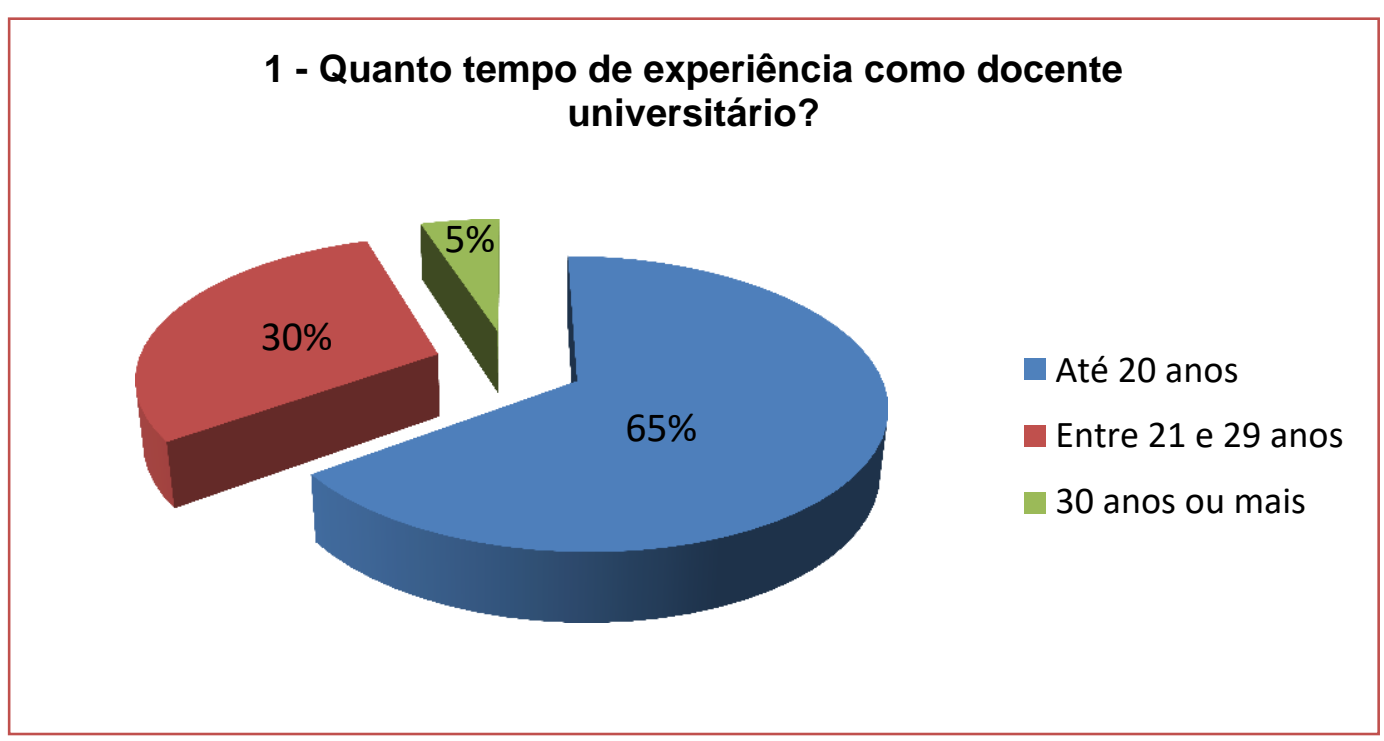

Fonte: Elaborado pelo autor

Questão 1: Em relação ao tempo de experiência como docente universitário, foi constatado que 65\% possuem até 20 anos de experiência; 30\% entre 21 e 29 anos de experiência e apenas 5\% afirmou ter 30 anos ou mais de experiência.

Gráfico 2 - Pergunta 2

\section{2 - Na sua opinião a tecnologia é indispensável no universo educacional ?}

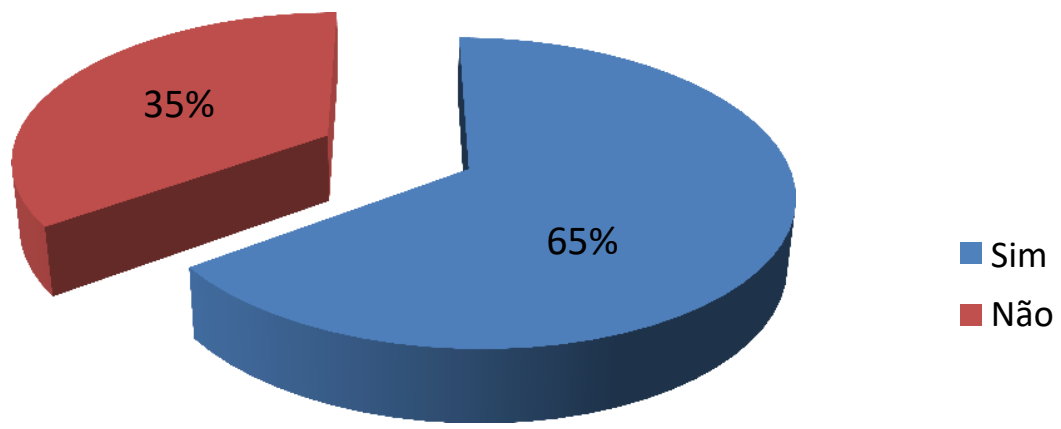

Fonte: Elaborado pelo autor 
Questão 2: Quando questionados sobre a indispensabilidade da tecnologia no universo educacional, 65\% afirmou que ela é indispensável, enquanto 35\% não acreditam que ela seja indispensável.

Gráfico 3 - Pergunta 3

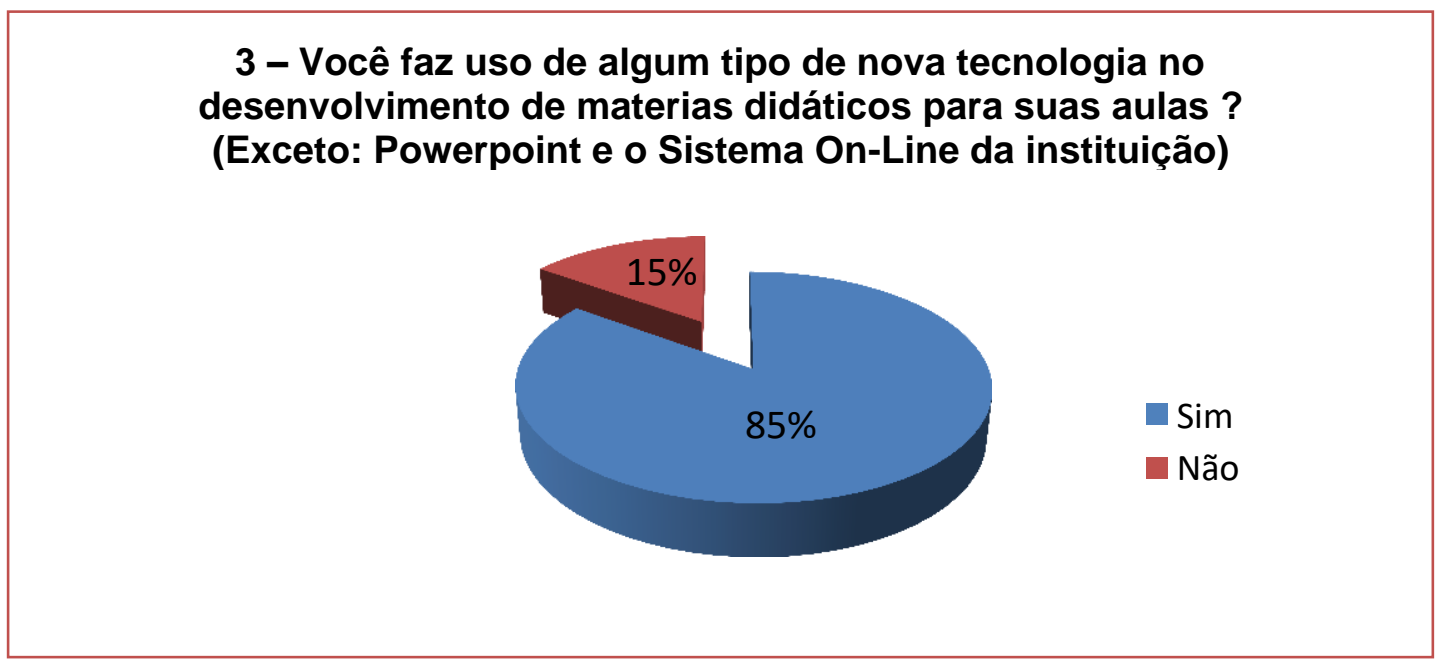

Fonte: Elaborado pelo autor

Questão 3: Em relação ao uso de novas tecnologias, 85\% declarou fazer uso, equanto 15\% afirmou não fazer uso de novas tecnologias no desenvolvimento de materiais didáticos para suas aulas.

Gráfico 4 - Pergunta 4

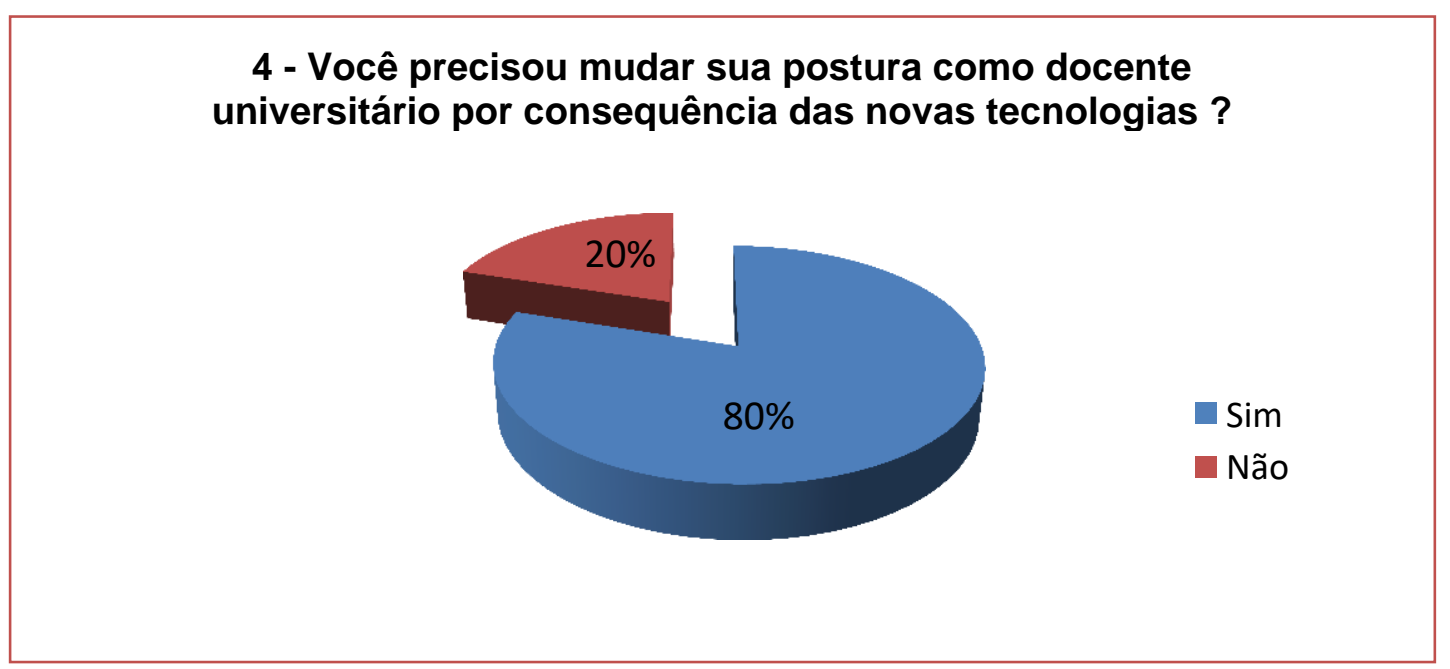

Fonte: Elaborado pelo autor

Questão 4: Quando indagados sobre se houve a necessidade da mudança de sua postura como docente universitário por consequência das novas tecnologias, 80\% afirmou que sim, precisou mudar sua postura, $20 \%$ afirmou que não houve a necessidade. 
Gráfico 5 - Pergunta 5

\section{5 - Na sua percepção a tecnologia para o universo educacional trouxe mais vantagens ou desvantagens para a educação?}

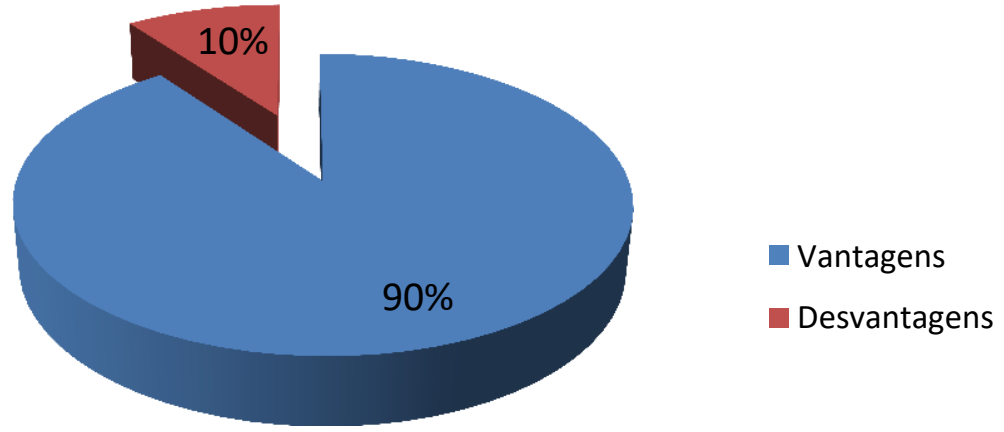

Fonte: Elaborado pelo autor

Questão 5: Quando perguntados se a tecnologia trouxe mais vantagens ou desvantagens para o universo educacional na percepção dos docentes, 90\% constatou que a tecnologia trouxe mais vantagens, 10\% afirmou que a presença da tecnologia no universo educacional ocasionou mais desvantagens.

Na próxima seção apresenta-se a análise e discussão dos resultados obtidos.

\subsection{ANÁLISE E DISCUSSÃO DOS RESULTADOS}

Analisando os dados obtidos podemos tirar algumas conclusões. Dentre os docentes da amostragem, 65\% afirmou que a tecnologia é indispensável no universo educacional, a grande maioria salientou que os alunos dessa nova geração já estabeleceram a tecnologia no seu processo de aprendizagem e que não a como o professor não utiliza-las. Esse resultado coincide com o pensamento de Lima (2000), aonde ele diz que as pessoas precisarão ser mais atuantes e que o papel da educação não será mais o de "enlatar" o conhecimento, o seu papel será o de ensinar as pessoas a filtrarem as informações relevantes para o seu aprendizado.

Sobre a postura, 80\% declarou que "sim", precisou mudar sua postura por consequência das novas tecnologias, alguns docentes explicaram que tiverem que mudar de postura ou adaptá-la pois já é uma exigência das IES, aonde o professor precisou trocar seus materiais padrões e começaram a usar novos mecanismos e softwares que aprimoram os métodos de ensino, mas exigem uma postura mais flexível do professor. A afirmação desses docentes concorda com as mudanças esperadas por Ramal (2002), ele dizia que iriam ocorrer grandes mudanças por consequência da tecnologia, o autor propôs três cenários e um deles se enquadra neste resultado, o cenário que foi intitulado de cibereducação integradora, neste cenário a educação se torna híbrida, é preciso da presença da tecnologia e também do homem. 
Quando perguntados sobre as vantagens e desvantagens das novas tecnologias no universo educacional, $90 \%$ dos docentes afirmaram que as novas tecnologias trouxeram mais vantagens, pois a tecnologia disponibilizou a uma grande parte das pessoas a possibilidade de acesso a informações que antes eram inacessíveis. Agora os professores podem se adaptar de forma contínua, escolhendo as ferramentas e processos que melhor se adéquem a cada turma ou situação, com o apoio das novas tecnologias e transformando a aprendizagem antes "engessada" em conceitos em algo mais dialético. Lima (2000) já afirmava a necessidade desta mudança, que colocaria a educação em todas suas modalidades de manifestação e transformaria o nosso existir em um processo dialético de educação permanente.

Na próxima seção apresenta-se as considerações finais.

\section{CONSIDERAÇõES FINAIS}

O desenvolvimento do presente trabalho proporcionou a análise do impacto do uso da tecnologia no espaço laboral universitário, com foco nos docentes. Além disso, possibilitou uma pesquisa em campo para se obter dados relevantes e consistentes relacionados ao tema.

Ao decorrer da pesquisa do referencial teórico, foi verificado que a maior parte dos autores pesquisados já presumiam a partir de suas pesquisas e estudos as mudanças que vêem ocorrendo atualmente no universo educacional, a mudança que mais foi citada por eles, é a necessidade dos docentes mudarem sua postura para se adaptarem as demandas que as novas tecnologias iriam estabelecer

A partir dos resultados obtidos através da aplicação das técnicas metodológicas, verificou-se o real impacto da tecnologia no universo dos docentes universitários. Ao tabular os resultados dos questionários com perguntas fechadas foi possível observar a real situação dos docentes, onde a maioria concorda que a tecnologia é vantajosa e indispensável para o seu universo laboral, mas também ressaltaram que só é vantajosa quando usada da maneira correta é no universo educacional. Ao analisar os resultados obtidos dos gráficos 3 e 4 é possível afirmar que boa parte dos docentes já assimilaram a tecnologia no seu espaço laboral e adaptaram sua postura por consequência do uso da tecnologia, demonstrando que os autores estavam certos quando citaram que os docentes precisariam mudar sua postura por uma demanda imposta pelas novas tecnologias, a maior parte dos docentes afirmaram que foi algo natural e agradável, pois ao incluírem novas tecnologias eles verificaram as grandes vantagens que essas ferramentas trariam para suas aulas.

Dada a importância do assunto, considera-se para futuros pesquisadores que venham a pesquisar o tema, que busquem utilizar uma amostragem maior e com uma faixa etária mais ampla, sendo proposto que verifiquem também a percepção dos discentes, pois são um dos principais interessados no assunto. 


\section{REFERENCIAS}

[1] BARRETO, R.G. Formação de professores, tecnologias e linguagens: mapeando novos e velhos (des)encontros. São Paulo: Loyola, 2002.

[2] FONSECA, J. J. S. Metodologia da pesquisa científica. Fortaleza: UEC, 2002. Apostila.

[3] FRANCO, M.L.B. Qualidade do ensino: velho tema, novo enfoque. Cadernos de Pesquisa, São Paulo, 1992.

[4] GIL, Antonio Carlos. Como elaborar projetos de pesquisa. 4. ed. São Paulo: Atlas, 2008.

[5] GIL, Antônio Carlos. Métodos e técnicas de pesquisa social. 5. ed. São Paulo: Atlas, 1999.

[6] JOLY, M. C. R. A. A tecnologia no ensino: implicações para a aprendizagem. 1. Ed. São Paulo: Casa do Psicólogo, 2002.

[7] LÉVY, P. As tecnologias da inteligência: o futuro do pensamento na era da informática. Rio de Janeiro: Editora $34,1993$.

[8] LÉVY, P. Cibercultura. São Paulo: Loyola, 1999.

[9] LIMA,Frederico O. A sociedade digital: o impacto da tecnologia na sociedade, na cultura, na educação e nas organizações, 2000.

[10] MARCONI, Marina de A; LAKATOS, Eva Maria. Técnicas de Pesquisa. São Paulo: Atlas Ed., 2002.

[11] 282p.

[12] MARTIN, Chuck; MARTIN, Charles. The Digital State. New York, USA: McGraw - Hill Companies, 1997.

[13] MAZZOTTI, A.J. O “aluno da escola pública”: o que dizem as professoras. Revista Brasileira de Estudos Pedagógicos, Brasília, DF, v. 87, n. 217, p. 349-359, 2006.

[14] PALFREY, Jhon; GASSER, Urs. Nascidos na era digital: Entendendo a primeira geração de nativos digitais, 2011.

[15] RAMAL, A.C. Educação na cibercultura: hipertextualidade, leitura, escrita e aprendizagem. Porto Alegre: Artes Médicas, 2002.

[16] RODRIGUES, A. M. M. Por uma filosofia da tecnologia. In. Grinspun, M.P.S.Z.(org) Educação Tecnológica Desafios e Perspectivas. São Paulo: Cortez, 2001: 75-129

[17] TAPSCOTT, Don. Geração Digital: A crescente e irreversível ascensão da Geração Net. São Paulo: Makron Books, 1999.

[18] TAPSCOTT, Don. A Hora da Geração Digital. Rio de Janeiro: Agir Negócios, 2010.

[19] ZUFFO, J.A. A tecnologia e a infossociedade. São Paulo: Manole, 2002. (A sociedade e a economia do novo milênio, v. 1).

\section{WEBGRAFIA}

Você corre risco de perder o emprego para um robô?. Disponível em: <www.bbc.com/portuguese/curiosidades-38979057>. Acesso em: 11 de setembro 2017.

Robôs vão substituir maioria das profissões, diz professor. Disponível em: <exame.abril.com.br/carreira/robos-vao-substituir-maioria-das-profissoes-diz-professor/>. Acesso em: 11 de setembro 2017. 
Como surgiu o EAD?. Disponível em: < http://www.ead.com.br/ead/como-surgiu-ensino-adistancia.html>. Acesso em: 30 de outubro 2017. 


\section{Capítulo 4}

\section{A importância da inteligência emocional no ambiente corporativo na visão de jovens universitários}

\section{Elizangela Oliveira Jesus \\ Wanderson Silva Damião \\ Erick Dawson de Oliveira \\ Letícia Soares Carvalho}

Resumo: A Inteligência Emocional é um assunto bastante discutido nas organizações modernas, pois, quando considerada e utilizada pelas empresas pode ser uma grande fonte de vantagem competitiva. Dessa forma, esse estudo de caso tem como objetivo evidenciar a importância da inteligência emocional no ambiente organizacional na visão de jovens universitários de uma Instituição de Ensino Superior da Baixada Santista. Foi realizada uma pesquisa descritiva e quantitativa, com aplicação de questionários para uma população de 60 jovens universitários, retornando uma amostra de 56 respondentes. Os dados coletados foram tabulados e submetidos a uma análise estatística simples. Pode-se analisar a relação entre a inteligência emocional aliada á liderança e á motivação. Percebeu-se também o quanto a inteligência emocional é importante no ambiente de trabalho e o quanto os jovens universitários valorizam sua prática no espaço laboral. Portanto, a inteligência emocional passou a ser um diferencial competitivo, visto que o século XXI aponta um cenário de desequilíbrio emocional, marcado pelas pressões por resultados financeiros e doenças ocupacionais.

Palavras chave: inteligência emocional; gestão de pessoas; motivação. 


\section{INTRODUÇÃo}

O mundo está cada vez mais acelerado, as transformações e mudanças acontecem o tempo todo fazendo com que as pessoas se tornem mais competitivas, descontroladas e mais impulsivas em suas decisões, diante desse cenário percebe-se o quanto a sociedade está carente de Inteligência Emocional, e isso também se reflete para a vida profissional onde muitos já não possuem motivação e autocontrole.

A Inteligência Emocional é a capacidade de reconhecer os próprios sentimentos e emoções, sabendo gerenciá-los de maneira positiva, e não somente os seus como também os das outras pessoas. Seu conceito no mundo foi disseminado através do psicólogo Daniel Goleman, no ano de 1995, porém anteriormente alguns autores já haviam pesquisado a respeito de certas características dessa inteligência, tais como Howard Gardner em sua Teoria das Inteligências Múltiplas e Peter e Salovey que foram os autores da Teoria da Inteligência Emocional.

Justifica-se a escolha do tema no âmbito acadêmico uma vez que através de pesquisas nos sites da ANPAD, SCIELO e BDTD, retornaram 95 artigos nacionais num período compreendido entre os anos de 2010 e 2017, deixando evidente que é um tema bastante relevante e de importante abrangência atualmente.

No âmbito de mercado, justifica-se a escolha do tema, pois as empresas são constituídas por pessoas, sendo elas o fator mais importante a ser investido e gerenciado, logo faz-se necessário trabalhar com profissionais devidamente equilibrados em suas emoções a fim de se ter comportamentos satisfatórios para o atingimento dos objetivos e alcance do sucesso organizacional.

Já no âmbito da autora, justifica-se a escolha do tema uma vez que a mesma possui formação acadêmica na área de pessoas, com interesse em seguir carreira e estudos científicos na área de comportamento e desenvolvimento humano.

O objetivo geral do artigo presente é evidenciar a importância da inteligência emocional no ambiente organizacional. Para que se consiga atingir esse objetivo o presente artigo tem como proposta estudar a influência da Inteligência Emocional na visão de jovens universitários. Analisar o potencial da Inteligência Emocional nos resultados da organização. Identificar estratégias para a promoção da Inteligência Emocional nas organizações.

É fácil perceber o quanto a sociedade está doente emocionalmente, cada dia mais são notícias e informações de suicídio, depressão, homicídios, separações, brigas, entre outras características evidentes da falta de equilíbrio emocional e de autocontrole. Mediante a esse cenário caótico que não afeta somente a vida em sociedade, mas também a vida profissional e corporativa, vale refletir: É importante se falar de Inteligência Emocional? As pessoas têm buscado desenvolver ou gerenciar da maneira certa suas emoções?

A fim de responder esses questionamentos, o presente trabalho está estruturado em três seções, a primeira trata-se do referencial teórico, discorrendo sobre a inteligência emocional, a gestão de pessoas e a motivação no trabalho; na sequência seguinte apresenta-se a metodologia utilizada na pesquisa; na terceira seção será apresentada a análise e discussão dos dados coletados e por fim na ultima seção tratase das considerações finais. 


\section{APORTE TEÓRICO}

O presente capítulo está dividido em três seções: Inteligência Emocional, Gestão de Pessoas e Motivação no Trabalho.

\subsection{INTELIGÊNCIA EMOCIONAL}

Discorrer sobre Inteligência Emocional é falar de autoconsciência, autocontrole, autoconhecimento e entre muitos outros fatores que estão internos e intrínsecos a cada indivíduo, cabendo a ele ter a decisão por desenvolver e gerenciar tais fatores.

A sociedade encontra-se em um momento caótico, a cada dia se ouve mais e mais notícias de homicídios, abusos, usos de drogas, brigas, discussões, separações, depressão e suicídios, deixando um alerta do quanto as pessoas estão com suas emoções e sentimentos descontrolados e desequilibrados, e refletindo o quanto a sociedade está emocionalmente doente (GOLEMAN, 1995).

Esse cenário também se repete nas organizações, pois com o aumento da competitividade, as pessoas tornaram-se mais ansiosas, mais aceleradas e na maioria das vezes sem equilíbrio emocional, pois focam somente na Inteligência Intelectual que é de suma importância para a vida profissional, mas deve ser alinhada com a Inteligência Emocional a fim de trazer resultados positivos não só para o colaborador mas também para a empresa (WEISINGER, 2001). Assim, no tópico a seguir será apresentado um breve histórico da inteligência emocional.

\subsubsection{BREVE HISTÓRICO}

A história da Inteligência Emocional tem início através dos estudos de Edward L. Thorndike, um psicólogo americano que em 1920 criou o conceito de Inteligência Social, que segundo ele era a capacidade de compreender e se relacionar com o outro. Em 1983, Howard Gardner, outro psicólogo americano questionou os testes de Coeficiente de Inteligência (QI) que eram realizados, sugerindo uma abrangência maior sobre as inteligências dos indivíduos, e assim após diversos estudos originou a Teoria das Inteligências Múltiplas, sendo elas: corporal-cinestésica; espacial; linguística; lógico-matemática; naturalista; musical; e as pessoais, sendo interpessoais e intrapessoais (OLIVEIRA, 2015).

Através dos estudos sobre a Teoria da Inteligência Social de Thorndike e sobre as inteligências pessoais da Teoria das Inteligências Múltiplas de Gardner, baseados nessas duas teorias os psicólogos estadunidenses John D. Mayer e Peter Salovey foram os autores da Teoria da Inteligência Emocional, que de acordo com eles é identificar os próprios estados emocionais e também os dos outros, usando-os para solucionar conflitos e problemas e gerenciar melhor os comportamentos (SALOVEY; MAYER, 1990).

Foi então que em 1995, o psicólogo Daniel Goleman através de pesquisas e com base nos estudos feitos por Salovey e Mayer, publicou seu livro "Inteligência Emocional", conceituando inteligência emocional como a capacidade de se automotivar, de ser persistente embora surjam imprevistos, sabendo reconhecer 
os próprios sentimentos e emoções e também os dos outros, sendo autoconfiante, conseguindo administrar assertivamente suas emoções e seus relacionamentos. Dessa forma ele disseminou o conceito de Inteligência Emocional e afirmou que para uma pessoa obter sucesso no âmbito mental dependerá de como administra tanto as suas emoções, quanto as emoções alheias (GOLEMAN, 1995).

O tópico a seguir irá apresentar a influência da inteligência emocional no trabalho.

\subsubsection{A INTELIGÊNCIA EMOCIONAL NO TRABALHO}

O primeiro convívio social que uma pessoa tem é em seu ambiente familiar, sendo a família o primeiro responsável pelo seu desenvolvimento emocional (OLIVEIRA, 2015), após se tornar adulto todas as suas vivências e experiências adquiridas na infância, adolescência e juventude forjaram a sua inteligência, refletindo no seu desempenho profissional.

As pessoas passam a maior parte de sua vida no trabalho, é lá onde suas emoções e seus comportamentos são manifestados com mais frequência, devendo-se assim possuir equilíbrio e inteligência emocional, pois seus estados emocionais influenciam diretamente seus comportamentos e desempenhos no ambiente organizacional (VALLE, 2006).

As pessoas são as peças fundamentais para o sucesso organizacional, pois são elas quem está no dia-a-dia da organização a fazendo executar sua missão e projetos. Trabalhar com profissionais qualificados e equilibrados emocionalmente é primordial para o bom desenvolvimento empresarial, visto que hoje a competitividade aumenta e exige cada vez mais pessoas com diferencial. Para se ter e manter pessoas com potencial e eficiência, a organização precisa gerenciar devidamente seus recursos humanos, o capítulo a seguir irá explanar sobre a gestão de pessoas.

\subsection{GESTÃO DE PESSOAS}

O mundo está em constantes mudanças e o mercado de trabalho tem exigido cada vez mais profissional altamente qualificado e com competências individuais que influenciam no atingimento das metas e sucesso organizacionais. É devido esse cenário e a essa exigência que a gestão de pessoas vem assumindo um papel excepcional, sendo os responsáveis pelas mudanças e desenvolvimento profissional dos recursos humanos da organização.

Gestão de pessoas é uma função gerencial que atua com ações e decisões estratégicas orientando e administrando os comportamentos humanos dentro da organização, criando políticas e práticas que permitam a participação e colaboração mútua entre as pessoas a fim de se atingir os objetivos individuais e organizacionais (FILHO, 2011; SILVEIRA, 2013).

A Inteligência Emocional passou a ocupar um papel importante e a ser um diferencial dentro da gestão de pessoas, pois no cenário atual ter somente conhecimento intelectual já não é mais garantia de bom desempenho e controle dos processos que envolvem as pessoas, é necessário que os gestores e líderes 
possuam Inteligência Emocional para lidar com os inúmeros desafios que ocorrem no dia-a-dia da organização. Assim, o tópico a seguir irá explanar sobre a liderança.

\subsubsection{LIDERANÇA}

O líder tem demasiada participação no desempenho e no comportamento de seus liderados, auxiliando-os e impulsionando-os a crescer, a se desenvolver e a serem eficazes profissionalmente, as pessoas precisam ser estimuladas e gerenciadas assertivamente para que se consiga extrair o melhor delas dentro da organização, conhecendo seus objetivos e suas motivações internas.

Liderar é ter a capacidade de influenciar e persuadir pessoas, incentivando-as a serem melhores, desenvolvendo seus potenciais para se atingir os objetivos almejados individualmente e organizacionalmente (SILVA, 2007).

Um líder que possui Inteligência Emocional, terá comportamentos interpessoais significativos, terá empatia para entender e compreender as emoções de seus liderados, terá flexibilidade para lidar com os diversos desafios em equipe conseguindo ter muito mais facilidade para conduzir sua equipe a atingir bons resultados e a alcançarem o máximo de seu potencial. E um dos comportamentos que o líder terá é uma maneira objetiva de se comunicar com seus liderados, conforme o tópico a seguir iráapresentar.

\subsubsection{COMUNICAÇÃO}

Toda e qualquer organização precisa de uma comunicação clara e eficiente, visto que através da comunicação a empresa pode modificar, melhorar, criar e inovar em muitos âmbitos e aspectos que não estejam favoráveis. É primordial para a existência de uma empresa e para sua solidificação no mercado, não sendo apenas um transmissor de informações, mas uma ferramenta estratégica que influencia nos relacionamentos e comprometimentos dos colaboradores (SILVA, 2016; RAMOS, 2014).

A comunicação é um ponto chave para se ter um bom ambiente de trabalho e fortalecer os relacionamentos, a Inteligência Emocional refletirá positivamente no desempenho da comunicação dos líderes e gestores, permitindo que os mesmos conheçam os sentimentos e emoções de seus liderados, criando um ambiente de confiança e parceria, através de uma comunicação eficiente e objetiva, possuindo flexibilidade para lidar com os desafios e estimular suas equipes a desenvolverem mais e mais a motivação, assunto que será abordado na sequência.

\subsection{MOTIVAÇÃO NO TRABALHO}

Um assunto muito abordado e requisitado no mundo do trabalho é a motivação, é perceptível o quanto as organizações exigem e prezam por profissionais motivados, que tenham proatividade e envolvimento no desempenho de suas tarefas e funções. Ninguém motiva ninguém, a motivação é algo interno e intrínseco a cada indivíduo, mas pode ser estimulada e desenvolvida através da Inteligência Emocional.

A motivação é uma força interior, originada por algum objetivo, motivo ou necessidade internos do indivíduo, que o impulsiona e o move a uma ação de persistência e ousadia, dirigindo seu comportamento 
a ir em busca de algo que se deseja alcançar (CRESTANI, 2015). Através da motivação o colaborado estará mais engajado com os objetivos organizacionais, não medirá esforços para se dedicar no trabalho, buscando sempre contribuir de forma significativa para o seu crescimento profissional, como também para o crescimento da organização.

A Inteligência Emocional influencia no desenvolvimento de fatores intrapessoais, que permitirão que o indivíduo faça uma reflexão de si mesmo e perceba o quanto precisa e pode melhorar, tais como a autoconsciência, o autoconhecimento e o autocontrole que capacitarão o colaborador a ter a percepção do quanto pode crescer e se realizar, levando-o a se motivar e persistir em uma meta que almeja atingir.

O sucesso de uma empresa vem através das pessoas que ali atuam, profissionais com Inteligência Emocional serão muito mais participativos e entrosados no ambiente de trabalho, estarão mais motivados e dispostos a crescer profissionalmente e a contribuir com a visão de futuro da empresa. Uma vez que os colaboradores se motivam e se unam a fim de atingir os objetivos organizacionais, terão muito mais chances de se sentirem confiantes e satisfeitos no trabalho, tendo motivação para chegar onde desejam, evoluindo de forma contínua, eliminando comportamentos que sabotam o seu sucesso, melhorando sua qualidade de vida e contribuindo significativamente para o seu crescimento e o de sua organização.

Na próxima seção discute-se a metodologia abordada nesse estudo.

\section{METODOLOGIA}

O presente estudo, quanto ao método utilizado, pode ser classificado como estudo de caso que segundo Gil (2008) e Yin (2005) é um estudo profundo e detalhado, que leva em consideração o conhecimento de todos os aspectos investigados e que foca em um acontecimento atual dentro de um cenário real.

Quanto à abordagem, trata-se de uma pesquisa quantitativa que de acordo com Richardson (1999) e Fonseca (2002) é uma pesquisa que se caracteriza pelo uso da quantificação, tanto na coleta das informações quanto no tratamento delas por meios estatísticos, é enfatizada na objetividade e para expor as causas dos acontecimentos utiliza de linguagem matemática.

Quanto à natureza dos objetivos metodológicos a presente pesquisa é considerada descritiva, uma vez que busca descrever as características de determinada população ou determinado acontecimento, tendo como uma de suas técnicas padronizadas para a coleta de dados o questionário, sendo ele utilizado no presente estudo (GIL, 2008; VERGARA, 2004).

A técnica de coleta de dados trata-se de questionário visto que é um procedimento de investigação, que coleta informações da realidade, com o objetivo de conhecer as opiniões, os sentimentos e situações vivenciadas pelas pessoas (GIL, 1999). Foram aplicados questionários compostos por 5 questões para um universo de 60 alunos de cursos superiores de uma Instituição de Educação Superior da cidade Santos-SP. Desse universo, retornaram 56 resultados. Os dados foram tabulados e submetidos a uma análise estatística simples. 
Quanto à amostragem, a mais adequada foi a probabilística aleatória que segundo Mattar (2001) é um tipo de amostragem onde existe a probabilidade de cada elemento da população ser escolhido aleatoriamente, sendo diferente de zero, garantindo assim que as pessoas participantes foram escolhidas aleatórias e não pela escolha da pesquisadora. A figura 1 ilustra a metodologia utilizada no artigo.

Figura 1 - Metodologia utilizada no presente artigo
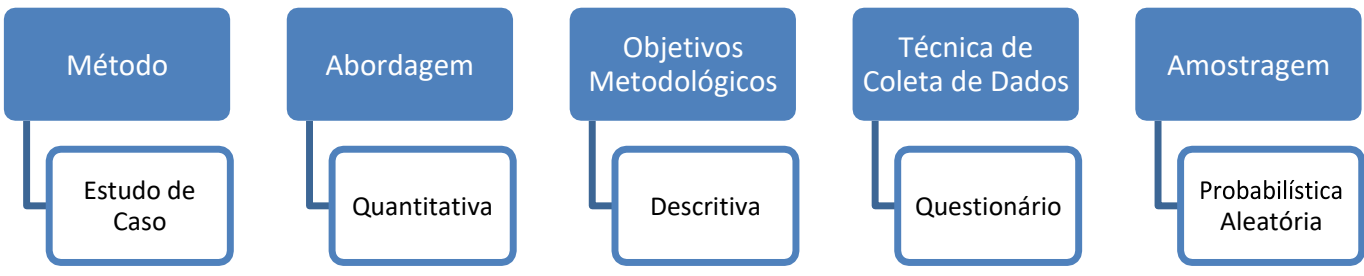

Fonte: Elaborado pela autora

A figura 1, acima apresentou de forma concisa e objetiva a metodologia empregada para a construção do presente artigo. Entre os métodos utilizados, destaca-se a pesquisa descritiva, uma vez que para atingir o objetivo desse artigo - evidenciar a importância da inteligência emocional no ambiente organizacional -, foi necessário colher informações e características de uma determinada população, no caso presente tratou-se de alunos universitários, através de questionários aplicados, os dados foram coletados, tabulados, analisados, e serão apresentados e discutidos na seção a seguir.

\section{APRESENTAÇÃO E DISCUSSÃO DOS RESULTADOS}

Após a aplicação da metodologia apresentada na etapa anterior, onde houve a realização de coleta de dados dos questionários os quais foram aplicados para um universo de 60 alunos universitários, retornando 56 resultados, e após a tabulação dos dados pode-se identificar que a grande maioria sabe o que é a inteligência emocional (75\%). Foram utilizadas 5 perguntas as quais apresentadas a seguir com a sequência de P1 a P5. 
Gráfico 1 - P1. Você sabe o que é inteligência emocional?

\section{P1. Você sabe o que é inteligência emocional?}

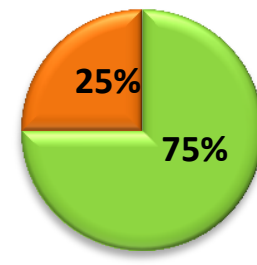

$\square \operatorname{Sim}$

$\square$ Não

Fonte: Elaborado pela autora

Analisando o gráfico 1 acima, pode-se afirmar que que 75\% dos respondentes sabe o que é inteligência emocional e que $25 \%$ não sabem. Já em relação ao quesito utilizar a inteligência emocional, o gráfico 2 aponta para:

Gráfico 2 - P2. Você utiliza da inteligência emocional em seu ambiente de trabalho?

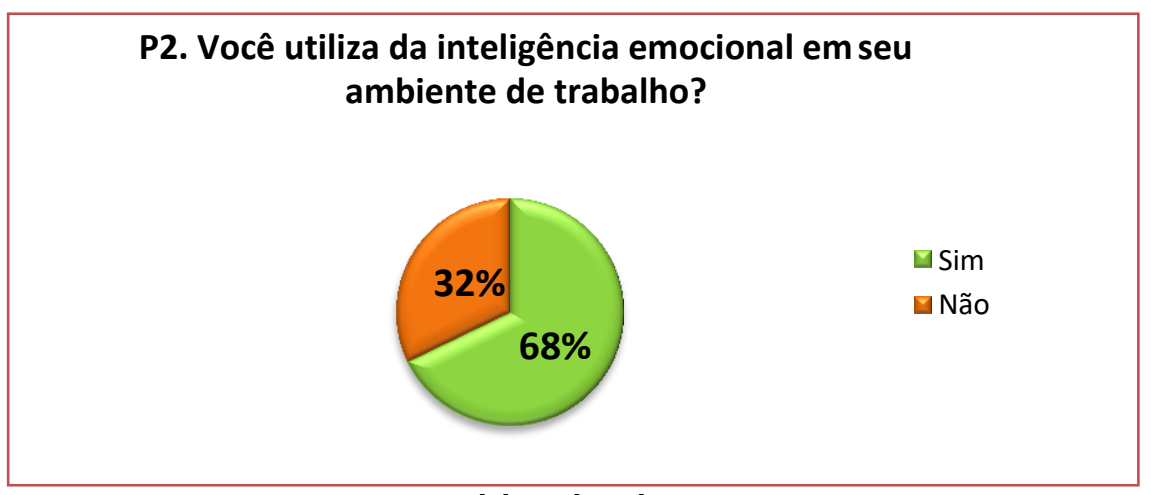

Fonte: Elaborado pela autora

Observando-se o gráfico 2 acima, pode-se analisar que 68\% dos respondentes utilizam a inteligência emocional no seu ambiente de trabalho e 32\% ainda não utilizam. Quando se perguntou sobre a empatia utilizada pelo gestor, os respondentes apontaram para o seguinte resultado do gráfico 3 : 
Gráfico 3 - P3. Seu líder ou gestor possui empatia sendo compreensivo com os liderados?

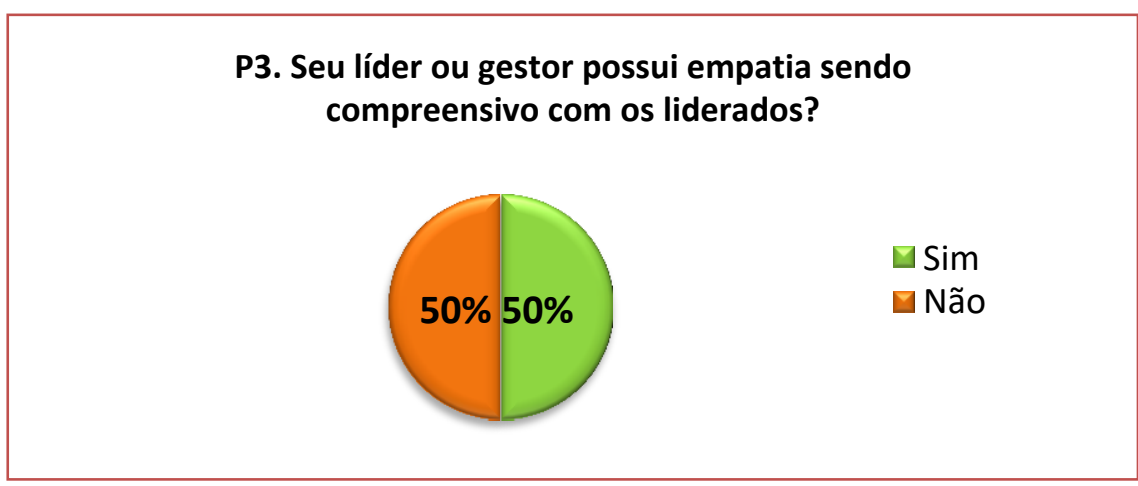

Fonte: Elaborado pela autora

Infere-se que ao observar o gráfico 3 acima que 50\% dos respondentes possui um líder empático e que $50 \%$ não possui. Por outro lado, ao se questionar sobre motivação, o gráfico 4 apontou para os seguintes resultados:

Gráfico 4 - P4. Você é motivado no trabalho?

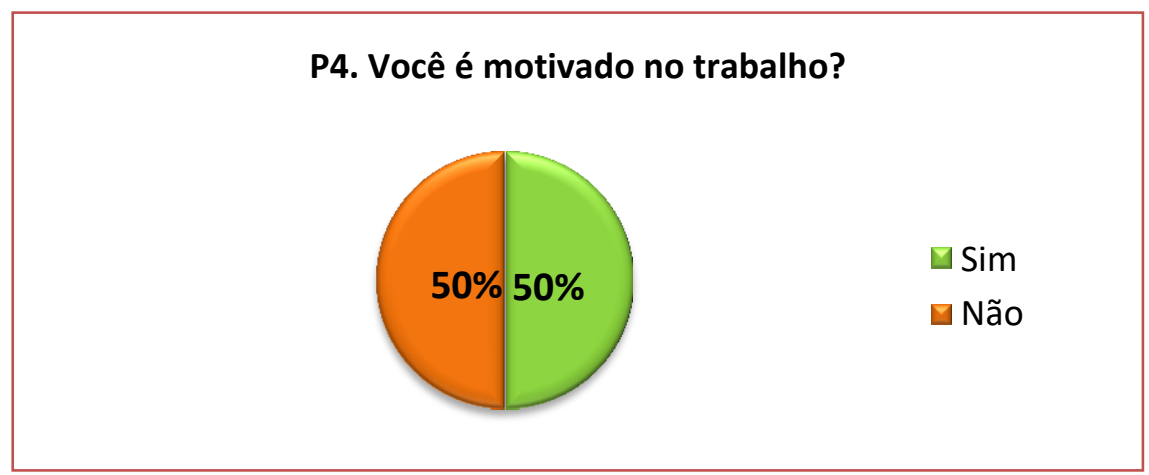

Fonte: Elaborado pela autora

0 gráfico 4 apresenta a questão da motivação no trabalho, deixando evidente que $50 \%$ dos respondentes são motivados no trabalho e que 50\% são desmotivados. E a respeito de utilizar a inteligência emocional no trabalho o gráfico apresenta os resultados: 
Gráfico 5 - P5. Você acha importante utilizar inteligência emocional no trabalho?

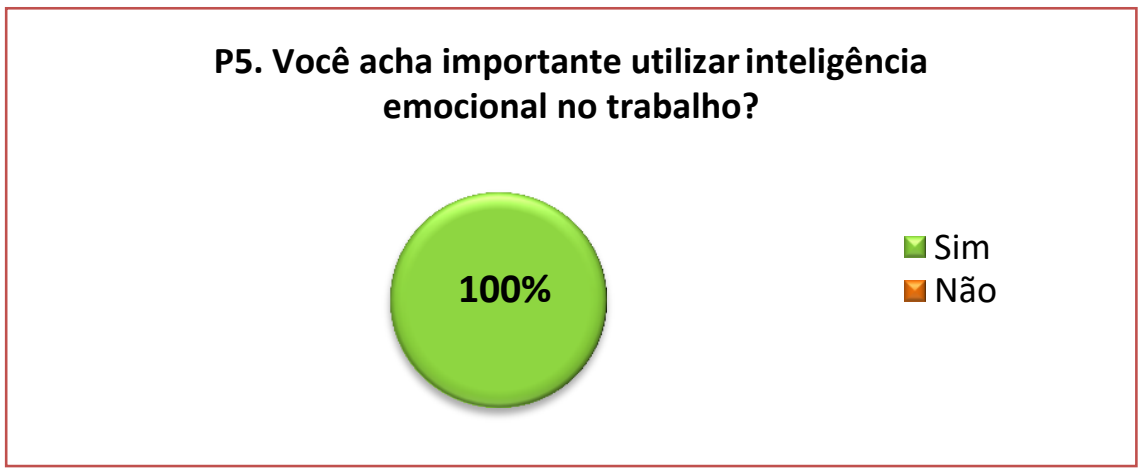

Fonte: Elaborado pela autora

Observa-se no gráfico 5 que 100\%, ou seja, todos os respondentes acham ser importante utilizar a inteligência emocional no ambiente de trabalho.

Ao analisar os gráficos expostos pode-se perceber na P2 (Gráfico 2) que a maioria dos respondentes utiliza da inteligência emocional em seu ambiente de trabalho (68\%), demonstrando o quanto as pessoas estão se atentando à importância que essa atitude possui, os benefícios que ela transmite no dia-a-dia profissional e o quão valioso é exercê-la no trabalho, pois conforme Valle (2006) os comportamentos e os desempenhos no ambiente organizacional serão significativamente influenciados e afetados pelas emoções do indivíduo.

Ao se observar as perguntas P3 e P4 (Gráfico 3 e Gráfico 4) percebe-se a igualdade entre as pessoas com líderes empáticos e compreensivos (50\%) e as pessoas que são motivadas no trabalho (50\%), nota-se o quanto a liderança influencia na motivação dos liderados, embora o líder não seja o responsável pela motivação de seu liderado, ele deve ter comportamentos e atitudes que o incentive a se motivar, visto que segundo Silva (2007), um líder deve ter capacidade para desenvolver seus liderados, influenciando-os serem mais envolvidos e motivados e um líder sem inteligência emocional, não terá empatia e percepção para saber o que seus liderados precisam e podem alcançar profissionalmente.

O último gráfico nos apresenta a P5 (Gráfico 5) onde pode-se ver que na visão de todos os respondentes a inteligência emocional é importante no ambiente de trabalho (100\%), deixando evidente que embora nem todos saibam descrever ou definir o que é a inteligência emocional (25\%), como foi perguntado na pergunta P1 (Gráfico 1), eles acreditam ser importante utilizá-la dentro das empresas visto que é uma capacidade essencial para se ter bons relacionamentos e alcançar sucesso mental e organizacional, como afirma Goleman (1995).

Na próxima seção discorre-se sobre as considerações finais desse estudo.

\section{CONSIDERAÇÕES FINAIS}

Após o desenvolvimento do presente estudo, pode-se evidenciar o quanto a Inteligência Emocional é significativamente importante e indispensável dentro das organizações, pois conforme o Gráfico 5 
apresentou anteriormente, todos os 56 respondentes acreditam que é importante no ambiente de trabalho utilizar a Inteligência Emocional. Pode-se perceber também o quanto a Inteligência Emocional influencia os comportamentos profissionais, visto que os Gráfico 3 e 4 demonstraram que o comportamento do líder está diretamente ligado à motivação do colaborador, confirmando assim que um líder que possui Inteligência Emocional conseguirá ter empatia com os seus liderados e como resposta a isso, conseguirá influenciá-los a se desenvolverem e estarem motivados no trabalho.

Uma empresa só consegue ter sucesso e crescer no mercado de trabalho se estiver em seu grupo de colaboradores pessoas empenhadas com o objetivo empresarial. A grande maioria dos respondentes sabe e utiliza da Inteligência Emocional no seu ambiente de trabalho, de acordo com os Gráficos 1 e 2, logo percebe-se o quanto os jovens enxergam a importância de se investir em Inteligência Emocional e ter controle de suas emoções e conseguir se motivar. Diante disso é indispensável ter profissionais motivados e equilibrados, pois serão mais produtivos e eficazes com competências que irão contribuir positivamente na organização, sendo capazes de ter maior autonomia na realização das tarefas e otimização dos seus resultados.

Sugere-se para futuras pesquisas a investigação sobre a visão dos docentes universitários a respeito da importância da Inteligência Emocional dentro da sala de aula, visto que eles possuem direta influência no desempenho de seus alunos e podem contribuir demasiadamente para o desenvolvimento da Inteligência Emocional deles e da manutenção da motivação.

Portanto, pode-se observar o quanto a Inteligência Emocional é um assunto atual da sociedade e do mercado de trabalho, e com o aumento das exigências profissionais, ela passou a ser um diferencial competitivo que muitas organizações estão buscando. Assim, vê-se que é necessário ter e utilizar da Inteligência Emocional pois trará melhorias entre os relacionamentos internos, no ambiente corporativo e consequentemente no sucesso organizacional, trazendo inúmeras satisfações não só para os colaboradores mas também para a organização.

\section{REFERÊNCIAS}

[1] CRESTANI, Rafaella Lacerda. Motivação, inteligência e inteligência emocional e suas relações com o desempenho acadêmico. - Pouso Alegre: Univás, 2015. Dissertação (Mestrado em Educação).

[2] FILHO, Oscar Julio. Gestão de pessoas nas pequenas e médias empresas do setor de calçados no Brasil: Avaliação do modelo de gestão de pessoas através de um estudo de caso. - Fundação Getúlio Vargas, 2011. Dissertação (Mestrado).

[3] FONSECA, J. J. S. Metodologia da pesquisa científica. Fortaleza: UEC, 2002. Apostila.

[4] GIL, Antônio Carlos. Como elaborar projetos de pesquisa. - 4⿳亠丷a ed. - São Paulo: Atlas, 2008.

[5] GIL, Antônio Carlos. Métodos e técnicas de pesquisa social. 5. ed. São Paulo: Atlas, 1999.

[6] GOLEMAN, Daniel, Ph.D. Inteligência emocional: a teoria revolucionária que redefine o que é ser inteligente. $10^{a}$ ed. - Rio de Janeiro: Objetiva, 1995.

[7] MATTAR, F. N. Pesquisa de marketing. 3 ed. São Paulo: Atlas, 2001. 
[8] OLIVEIRA, Aline Louise de. Qualidade de serviços em ensino: uma análise sob a perspectiva da inteligência emocional. - Blumenau: Universidade Regional de Blumenau, 2015. 115 f. Dissertação (Mestrado emAdministração)

[9] RAMOS, Sílvia Jurema da Silva. Gestão da comunicação organizacional na Fundação Joaquim Nabuco: o canal de comunicação Fale Conosco. - Recife: Universidade Federal de Pernambuco, 2014. Dissertação (Mestrado em Gestão Púbica).

[10] RICHARDSON, R. J. Pesquisa social: métodos e técnicas. 3. ed. São Paulo: Atlas, 1999.

[11] SALOVEY, P.; MAYER, J. D. Emotional intelligence. Imagination, cognition and personality, n. 9, p. 185-211, 1990.

[12] SILVA, Cássia Aparecida Lopes da. Comunicação organizacional na gestão do trabalho: papeis dos gestores de equipe e natureza da comunicação. - Porto Alegre: Universidade do Rio Grande do Sul, 2016. Dissertação (Mestrado em Comunicação e Informação).

[13] SILVA, Rovilson Dias da. A influência da liderança como estímulo à motivação de equipes virtuais. São Bernardo do Campo: Universidade Metodista de São Paulo, 2007. Dissertação (Mestrado em Administração).

[14] SILVEIRA, Victor Natanael Schwetter. Posturas estratégicas, práticas de gestão de pessoas e práticas de mensuração dos resultados e contribuições da gestão de pessoas para o desempenho organizacional: uma análise de suas relações e configurações. - Belo Horizonte: Universidade Federal de Minas Gerais, 2013. Tese (Doutorado em Administração).

[15] VALLE, Patrícia Barroso do. Inteligência emocional no trabalho: um estudo exploratório. - Rio de Janeiro: Faculdades Ibmec, 2006. Dissertação (Mestrado em Administração)

[16] VERGARA, Sylvia Constant. Projetos e relatórios de pesquisa em administração. - 5ª ed. - São Paulo: Atlas, 2004.

[17] WEISINGER, Hendrie, Ph.D. Inteligência emocional no trabalho: como aplicar conceitos revolucionários da I.E. nas suas relações profissionais. Reduzindo o estresse, aumentando sua satisfação, eficiência e competitividade. Rio de Janeiro: Objetiva, 2001. 219 p.

[18] YIN, Robert K. Estudo de caso: planejamento e métodos. - 3a ed. - Porto Alegre: Bookman, 2005. 


\section{Capítulo 5}

A inserção de uma ferramenta operacional tecnológica no processo de movimentação de contêineres na empresa Estrada em Santos/SP

Elizangela Oliveira Jesus

Victor Yan Bufoni Dias

Alice Nascimento Teixeira Rocha

Resumo: A discussão acerca das dificuldades enfrentadas pelo Porto de Santos e pelas organizações que nele respectivamente operam, faz se necessária para o desenvolvimento das atividades portuárias. São diversos os problemas gerados pela falta de investimentos no setor, principalmente por parte dos órgãos públicos e pelas empresas atuantes neste ramo, afetando a todos de modo geral, prejudicando possíveis avanços que poderiam ocorrer. A falta de organização no setor portuário é um dos maiores gargalos enfrentados no país, prejudicando desde a movimentação de carga até o cidadão comum. Por este motivo um projeto com o intuito de minimizar parte destes problemas, no caso, por meio da criação de uma ferramenta operacional tecnológica, após ser feita uma análise de dados apresentados pela empresa Estrada, visando a diminuição de custos e de tempo de operação, tanto de trânsito da mercadoria, como por meio da armazenagem e despacho, visando a otimização do processo de maneira holística.

Palavras chave: Inovação, investimentos, software. 


\section{INTRODUÇÃO}

Atualmente, o meio em que vivemos está constantemente em transição, no qual o ser humano além de ser o responsável por essas mudanças, precisa a todo o momento desenvolver mecanismos para lidar com elas, e com isso, a tecnologia tem sido forte aliada da população, e a cada avanço, maior é a sua precisão e facilidade nas operações, possibilitando cada vez mais sua utilização e implementação em diversos setores.

A Estrada, empresa na qual o projeto se orienta, tem como fundador Acrino Barboza de Freitas, e atua no transporte rodoviário de cargas, sendo especializada em Comércio Exterior. Desde 1982, procura estar atualizada nos meios tecnológicos, buscando evoluir seu nível de serviço, à medida em que o mercado se torna cada vez mais competitivo. No início, era situada nas proximidades do Porto de Santos e, com um processo de desenvolvimento e expansão, transferiu-se para locais estratégicos próximos dos principais portos e aeroportos do país, tendo atualmente unidades de operação, REDEX (Recinto Especial para Despacho Aduaneiro de Exportação), armazéns planejados e áreas próprias para o armazenamento inclusive de contêineres refrigerados, podendo ser encontrada em sete instalações em três estados brasileiros (São Paulo, Santa Catarina e Goiás).

Partindo do princípio que a agilidade nas operações se faz essencial neste ramo, foi identificada a necessidade do estudo de um meio que possibilite a melhora na movimentação de contêineres dentro do perímetro da corporação, e com isso, criou-se a ideia de um dispositivo que, ao ser interligado ao banco de dados do WMS (Sistema de Gerenciamento de Armazém), analise as informações obtidas e desenvolve estrategicamente decisões para melhorar o posicionamento destes contêineres, que estão constantemente em trânsito, dentro do pátio da empresa.

"O WMS [...] permite gerir a entrada da mercadoria, controle de remessa, estoques, gestão de lotes e rastreabilidade do fabricante ao ponto de venda. Assim é possivel traçar caminho, história, aplicação, uso e localização de uma mercadoria ou de uma carga em tempo real". (DIAS, 2012, p.330).

Sendo assim a Estrada que tem como missão oferecer aos clientes soluções e serviços logísticos em alta qualidade, poderá utilizar mais este recurso como aliado para o alcance da visão de consolidar-se como a melhor empresa nacional de soluções logísticas.

\section{OBJETIVO GERAL}

O objetivo deste estudo é disseminar a inovação, propondo a inserção desta ferramenta tecnológica operacional, que tem como intuito proporcionar a automatização do processo de movimentação, entrada, armazenagem e saída dos contêineres na empresa, propondo uma gestão mais eficiente e eficaz no segmento logístico, permitindo a realização de seu planejamento estratégico, minimizando os custos e maximizando os recursos e processos, visando a satisfação do cliente.

\section{OBJETIVO ESPECÍFICO}

O objetivo específico deste estudo é desenvolver um dispositivo versátil, que ao ser interligado ao software WMS, analisa informações e posiciona contêineres e indica a melhor posição para alocá-los, otimizando o tempo de operação e reduzindo demasiadamente margens de erros comuns neste ramo de atuação, melhorando de forma contínua a qualidade de serviços prestados. 


\section{METODOLOGIA}

Para a realização deste estudo, foram utilizadas pesquisas bibliográficas para fundamentar os conceitos teóricos apresentados. Também foram empregados eixos quantitativos estatísticos obtidos por meio de estudos, recursos virtuais e pesquisa de campo para a comprovação dos fatos apresentados, determinando a sua efetividade.

O projeto consiste na implementação de uma nova ideia tecnológica e sua utilização como aliada nas mais diversas fases de gestão de cargas. Para isso, foi feito um estudo inicial para levantamento de dados e posteriormente a análise crítica, formulando as situações e obtendo o auxílio do protótipo do software, demostrando a sua respectiva efetividade diante do cenário proposto, e finalizando com a sua inserção na empresa.

\section{DESENVOLVIMENTO}

A implementação de mecanismos tecnológicos em meios operacionais tanto em zonas primárias quanto em zonas secundárias, são de fundamental importância para o mundo nos dias de hoje, auxiliando diretamente na eficiência da empresa em realizar os seus processos no cotidiano, haja visto a empresa que não aprimora seus conceitos em tecnologia, encontra-se defasada no mercado, tendo em vista o capitalismo selvagem no qual estamos imersos, e a necessidade da informação rápida esta de grande utilidade e relevância, nas quais os clientes internos assim como os clientes finais o necessitam, sendo assim é inevitável o uso de ferramentas nos processos logísticos dos diversos setores operacionais, por meio de estudos e relatos, mais precisamente na empresa Estrada , o foco do nosso estudo, identificamos uma necessidade de aprimoramento em seu processo de movimentação de cargas com o propósito de otimizar o tempo de movimentação e o atendimento ao cliente, bem como os custos inerentes ao processo. Desde o início, quando encontrava-se em estudo de modelo de projeto, foram feitas análises quanto a sua viabilidade e abrangência nos segmentos estudados em sala de aula, diante de tais propostas, foram vastas as informações fornecidas, com maior aparato da empresa Estrada, nas quais foram elaboradas tabelas e gráficos para representar os respectivos dados. Assim apresentada para a Estrada como ideia de melhora de seus processos logísticos, foram feitas análises desde seus departamentos, nos quais os setores de atendimento ao cliente e controle de armazém disponibilizaram maiores informações, ainda neste âmbito foi constatada uma projeção de demanda cada vez maior no setor de movimentação de cargas intermodais. A Logística da empresa apresenta atualmente uma necessidade de crescimento a respeito de ideais tecnológicos, visto que para um bom funcionamento de operações, o fator que proporciona maior segurança é a Comunicação (softwares, sistemas integrados, redes).

O contêiner, originalmente desenvolvido para o transporte de cargas, é uma ferramenta indispensável na unitização e padronização no processo de movimentação de produtos manufaturados e semimanufaturados como, por exemplo: café, medicamentos, vestuários, autopeças, calçados, carnes, entre outros, tornando-se o centro de todo esse processo. Sendo esta ferramenta operacional de grande relevância econômica mundial, por meio de serem estruturas padronizadas de formato retangular, construídas em aço, sendo cada um deles registrados no Bureau International of Containers, organização não governamental que regulamenta o processo de contêineres e transporte intermodal pelo mundo. 
Figura 1 - A ferramenta operacional, o contêiner

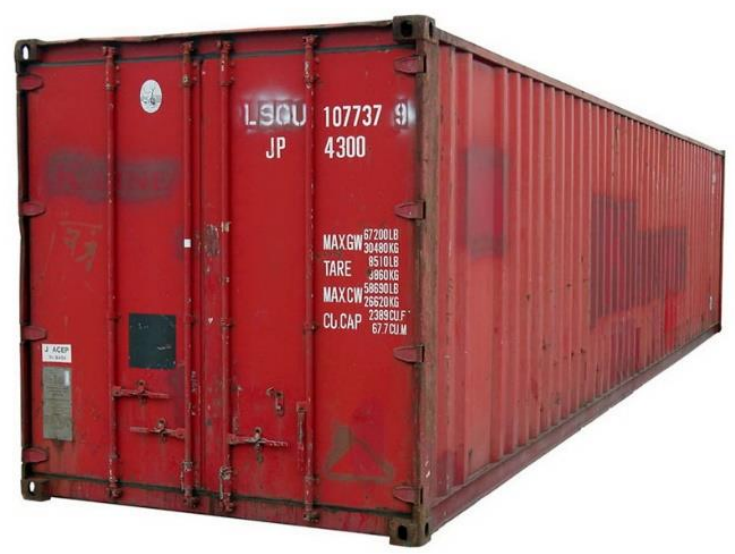

Fonte: Imagens do Google (2019)

Dentro de seu contexto histórico, pensando em uma forma de evitar deteriorações, perdas no transporte devido a quebras e fáceis desvios de mercadorias, o americano Malcom Mc Lean, com pouco mais de 20 anos e dono de uma empresa de transportes a Sea-Land, que posteriormente passou-se a se chamar Maersk-Sealand, teve a ideia de criar grandes caixas de aço, para que estas pudessem ser embarcadas em navios, oferecendo maior segurança e otimizando o método anteriormente utilizado que por sua vez encontrava-se defasado.

Atualmente, o uso deste equipamento vem aumentando gradativamente em consequência de sua essencialidade, o contêiner é utilizado em 95\% da movimentação de carga geral do transporte intermodal. Sendo que o Porto de Santos se manteve como o principal complexo na movimentação de contêineres da América Latina, no ranking de 2014 no qual foi divulgado pela publicação americana The Journal of Commerce, especializada em tráfego marítimo, segundo este o complexo portuário brasileiro é o $38^{\circ}$ porto do mundo na movimentação de contêineres, com o resultado de 3,68 milhões TEU's (unidade equivalente a um contêiner de 20 pés). 0 número mantém Santos na liderança da América Latina, superando, pelo segundo ano consecutivo, o Porto de Balboa, no Panamá. 0 porto panamenho registrou 3,47 milhões TEU's e está apontado na $42^{\circ}$ colocação do ranking mundial. Nas dez primeiras posições destacam-se portos chineses, estando posicionados três entre os quatros maiores do mundo, com destaque ao porto de Xangai na primeiro colocação, com registro de movimentação de 35,29 milhôes de TEU's.

Tabela 1 - Representatividade do complexo portuário santista (ranking - The Journal of Commerce)

\begin{tabular}{|c|c|c|c|c|c|}
\hline \multirow[b]{2}{*}{ Posição } & \multirow[b]{2}{*}{ Porto } & \multirow[b]{2}{*}{ Pais } & \multicolumn{2}{|c|}{ Movimentação (Milhões - TEU) } & \multirow[b]{2}{*}{ Crescimento } \\
\hline & & & 2014 & 2013 & \\
\hline $1^{0}$ & Xangai & China & 35,29 & 33,62 & $5 \%$ \\
\hline $2^{\circ}$ & Cingapura & Cingapura & 33,87 & 32,58 & $4 \%$ \\
\hline $3^{\circ}$ & Shenzhen & China & 24,03 & 23,28 & $3,20 \%$ \\
\hline $4^{\circ}$ & Hong Kong & China & 22,23 & 22,35 & $-0,60 \%$ \\
\hline $38^{\circ}$ & Santos & Brasil & 3,68 & 3,45 & $6,80 \%$ \\
\hline $42^{\circ}$ & Balboa & Panamá & 3,47 & $x x x x x x x x x x x x x x x$ & $x x x x x x x x x x x x x x x$ \\
\hline
\end{tabular}

Fonte: The Journal of Commerce (2014) 
O Brasil atua neste meio de transporte intermodal contando com 41 portos marítimos e 16 fluviais. Encontram-se entre os três maiores portos brasileiros em dados de movimentação de contêineres, o Porto de Paranaguá, no Paraná, o Porto de Vitória, no Espírito Santo e o Porto de Santos, no estado de São Paulo. Segundo dados apurados o complexo portuário santista alcançou a movimentação representativa de 3,68 TEU's, número $6,8 \%$ maior ante o ano anterior, voltando a assumir a 1a posição entre os portos da América Latina.

Figura 2 - Organograma hierárquico da empresa Estrada

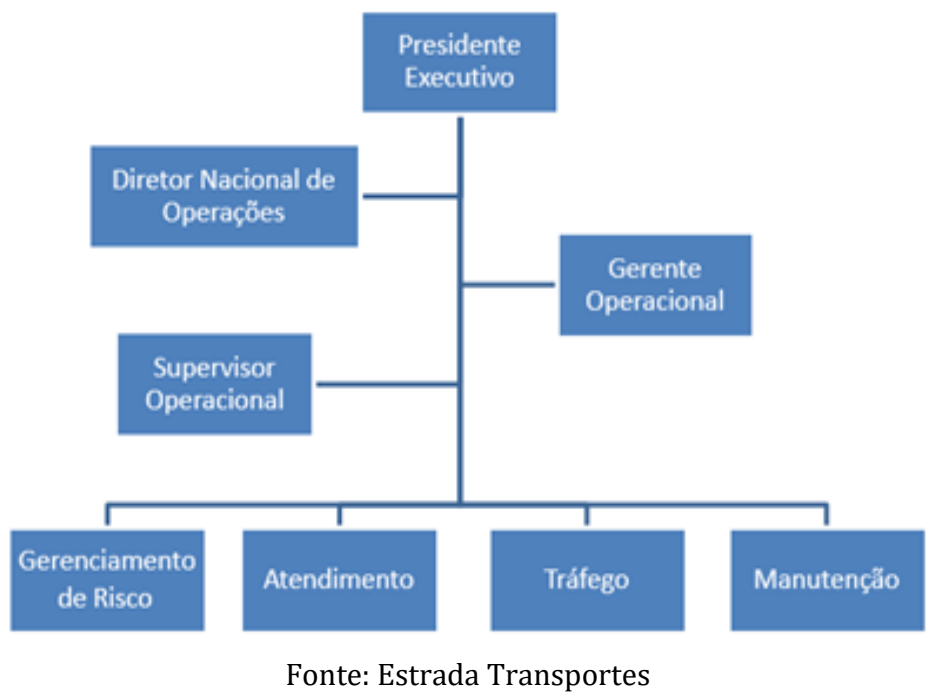

A Estrada cujo a sua visão é consolidar-se como a melhor empresa nacional de soluções logísticas no transporte de cargas gerais de Comércio Exterior e mercado interno, estava situada nas proximidades do porto de Santos, e devido ao seu processo de desenvolvimento e expansão, teve sua transferência para locais estratégicos, observando seus processos gerenciais internos, constata-se em seu respectivo organograma, como demonstrado na figura 2 , com seus departamentos acertadamente verticalizados. 0 presente estudo direcionado aos seus processos de movimentação e armazenagem de contêineres pôde ser desenvolvido com base em dados fornecidos pela própria empresa por meio do setor de Atendimento e constatado pela Gerência. Observam-se as seguintes estatísticas apontadas na tabela 2, na operação da empresa.

Tabela 2 - Movimentação da quantidade de contêineres (sazonalidade)

\begin{tabular}{|c|c|}
\hline \multicolumn{2}{|c|}{ QUANTIDADE DE CONTÊINER - MOVIMENTAÇÃO / DIA } \\
\hline Março à Outubro & Novembro à Fevereiro \\
\hline 60 à 80 & 20 à 40 \\
\hline TEMPO MÉDIO - MOVIMENTAÇÃO / CONTÊINER & Entre 3 à 8 minutos \\
\hline VALOR ESTADIA - CONTÊINER POR DIA & Entre US $\$ 50,00$ à US $\$ 70,00$ \\
\hline CUSTO MOVIMENTAÇÃO - MÁQUINA & Por CNTR US\$ 26,67 \\
\hline
\end{tabular}


Historicamente, apresenta dois períodos distintos, sendo que nos meses de Novembro à Fevereiro de cada período a empresa apresenta sazonalidade de baixa movimentação, já nos meses de Março à Outubro o período de alta movimentação, que deve-se pela safra ser maior nessa época do ano, dentro do cenário logístico da relação custo e movimentação, foi levantado um assunto que seguramente visualiza a melhora de todo o processo; o uso de tecnologia da informação como ferramenta aliada à empresa.

\section{1 A RELEVÂNCIA TECNOLÓGICA NO PLANO ESTRATÉGICO EMPRESARIAL}

A implementação de novas tecnologias é de fundamental importância para o mundo globalizado, haja vista, que a tecnologia tem auxiliado diretamente na eficiência das empresas em realizar os seus processos cotidianos. Atualmente, uma empresa que não utiliza recursos de tecnologia, como softwares, encontra-se defasada no mercado, tendo em vista o capitalismo selvagem no qual estamos imersos, e a necessidade da informação rápida já observada desde os primeiros indícios do avanço tecnológico, é imprescindível o uso de tais ferramentas no processo logístico dos mais variados setores.

Existem três pilares fundamentais para que uma atividade Logística de movimentação e armazenagem sejam realizada com eficiência: estrutura adequada, veículos capacitados e uma comunicação de ponta.

Um fato imutável é que o fator humano tem a maior contribuição nas falhas do encadeamento do trabalho, sobrepondo-se ao fator tecnológico que realiza suas atividades com maior exatidão e segurança.

“O desenvolvimento de estratégias e a tecnologia estão intimamente relacionados. Embora não possa ser totalmente automatizado, o uso criterioso de uma boa tecnologia certamente lhe permitirá promover uma boa comunicação, aumentar a criatividade e conferir estrutura a sua estratégia”. (MCKEAN, 2012, p. 127128).

Por meio de estudos e relatos, mais precisamente na empresa Estrada, identificamos a necessidade de aprimorar o processo de movimentação de cargas com o propósito de reduzir o tempo de movimentação e atendimento do cliente, bem como, os custos inerentes ao processo.

O objetivo deste estudo consiste em focar na redução de tempo para o remanejamento de contêineres em pátios e terminais, tornando este processo simples com o auxílio da ideia do software com base em horários de agendamento dos mesmos, permitindo diminuir gastos e tempo nas operações.

\section{2 A TANGIBILIDADE DO NÍVEL DE SERVIÇOS}

A excelência no desempenho de uma empresa está relacionado à capacidade e a qualidade do nível de serviços e a representatividade de seus fatores, sendo assim detectando as melhores formas de fazer novos melhoramentos, como no setor operacional, a inserção desta ferramenta é uma forma de inovação para um processo logístico mais eficiente e eficaz.

Concentrar-se nos resultados assumindo o compromisso com as metas a serem atingidas, com a contribuição de ideias, sugestões para o aperfeiçoamento da empresa, estas devem ser desafiadoras e realistas, na qual dará maior auxílio nos processos de entrada, armazenagem e na saída, reduzindo os custos de estufagem e espaço físico, agregando valor no maior nível de serviço, na confiabilidade com o consumidor e otimizando o tempo inserido para atender principalmente as expectativas e necessidades dos clientes. 
Figura 3 - Relação nível de serviço e sua representatividade

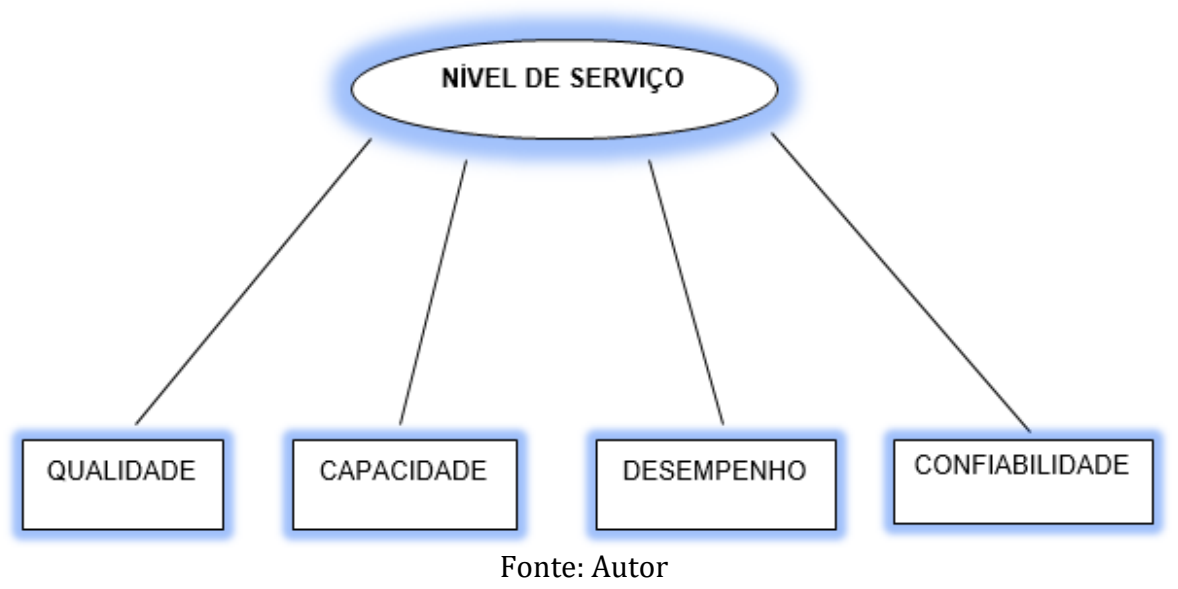

Esse critério é apropriado quando atende diferentes tipos de clientes, com necessidades ambíguas, ou quando são iguais, mas com carências bem diferentes, ter controle absoluto de modo a atingir o objetivo planejado.

\section{A SISTEMÁTICA DA FERRAMENTA TECNOLÓGICA OPERACIONAL}

0 setor enfrenta adversidades no que se refere à translação de cargas, isto é, a entrada, o armazenamento, os procedimentos alfandegários e a saída de contêineres. Com isto, vimos a necessidade de oferecer uma ideia de ferramenta tecnológica operacional, com o intuito de aprimorar a infraestrutura e a funcionalidade da movimentação dos contêineres, promovendo a eficiência na alocação destes.

"O sistema WMS através do seu princípio de convocação ativa e da sua habilidade em trabalhar com equipamentos de movimentação automatizados, propicia grande redução de custos com pessoal, além de reduzir a necessidade de equipamentos para a mesma quantidade de movimentações, se estas fossem feitas através de sistemas tradicionais" (DIAS, 2012, p.331).

O conceito se baseia em uma ideia de software integrado com o sistema em banco de dados, o WMS, consultando desta forma todos os horários de agendamento e entregas para que o planejamento logístico gere maior otimização e consequentemente maior produtividade dentro do pátio.

O sistema utiliza a seguinte metodologia: introdução e busca de informações no banco de dados feitas pelo setor comercial; verifica a disponibilidade de caminhões para entrega ou retirada de contêineres ao cliente; averiguação de desimpedimento de locais no pátio para armazenamento do contêiner, buscando a posição mais adequada de acordo com suas características e filtro de pesquisa rápida localização quando o mesmo for solicitado. 
Figura 4 - 0 layout do protótipo do sistema

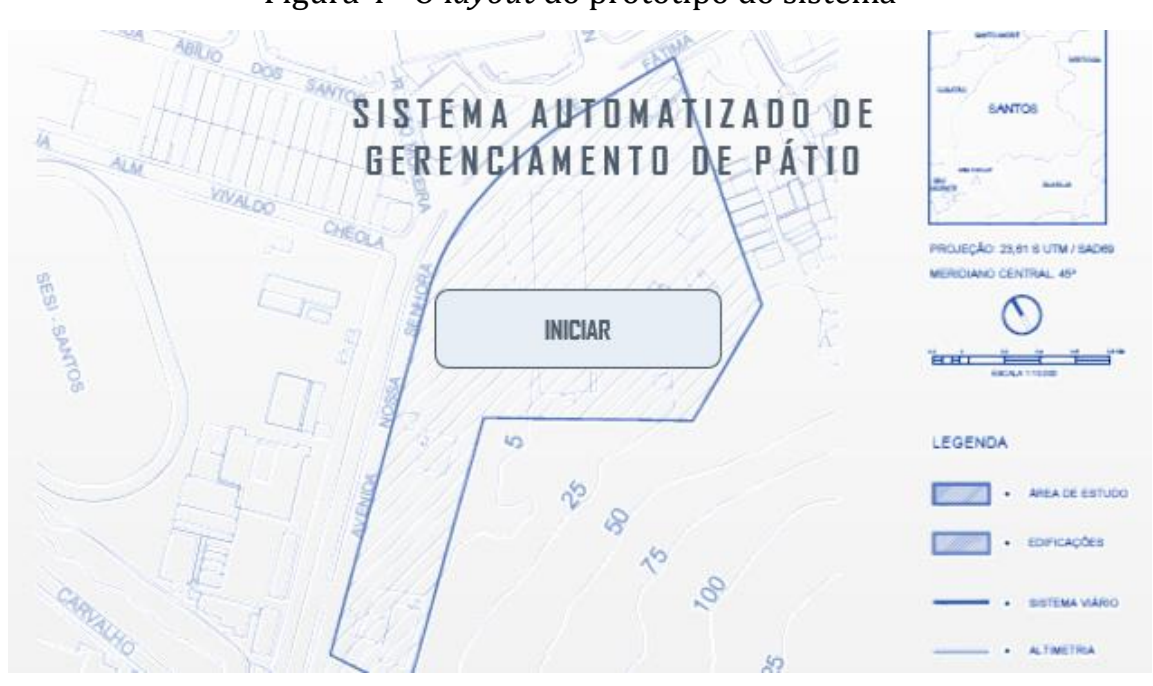

Fonte: Autor

Sendo assim o sistema tem o propósito da automatização de gerenciamento de pátio ser versátil e personalizado, integrando-se ao sistema WMS da empresa, no caso da Estrada, para captar as informações dos contêineres que fora previamente registrada após a negociação da prestação de serviço, como: previsão de entrada e saída do pátio, tipo de contêiner, número, nome da empresa, peso dimensões entre outros.

Ao processar estas informações, o sistema indicará qual é o melhor local para a alocação daquele contêiner e suas características específicas, em outras palavras, o sistema deve ser programado de acordo com o que o mesmo pode ou não fazer, Por exemplo: quando o dispositivo identificar que se trata de um contêiner refrigerado, ele deve buscar em sua configuração que deve ser previamente realizada, qual é a área do terminal destinada para contêineres daquele tipo, posteriormente, o dispositivo passa pelo processo de verificação de espaços disponíveis, que estejam aptos para receber aquele contêiner (analisando as dimensões, a altura permitida para empilhamento, a data prevista para saída, para que as pilhas já fiquem organizadas para o momento de sua retirada, entre outros processos de eficiência logística para a correta alocação dos contêineres.

Figura 5 - A área de atuação do software na empresa

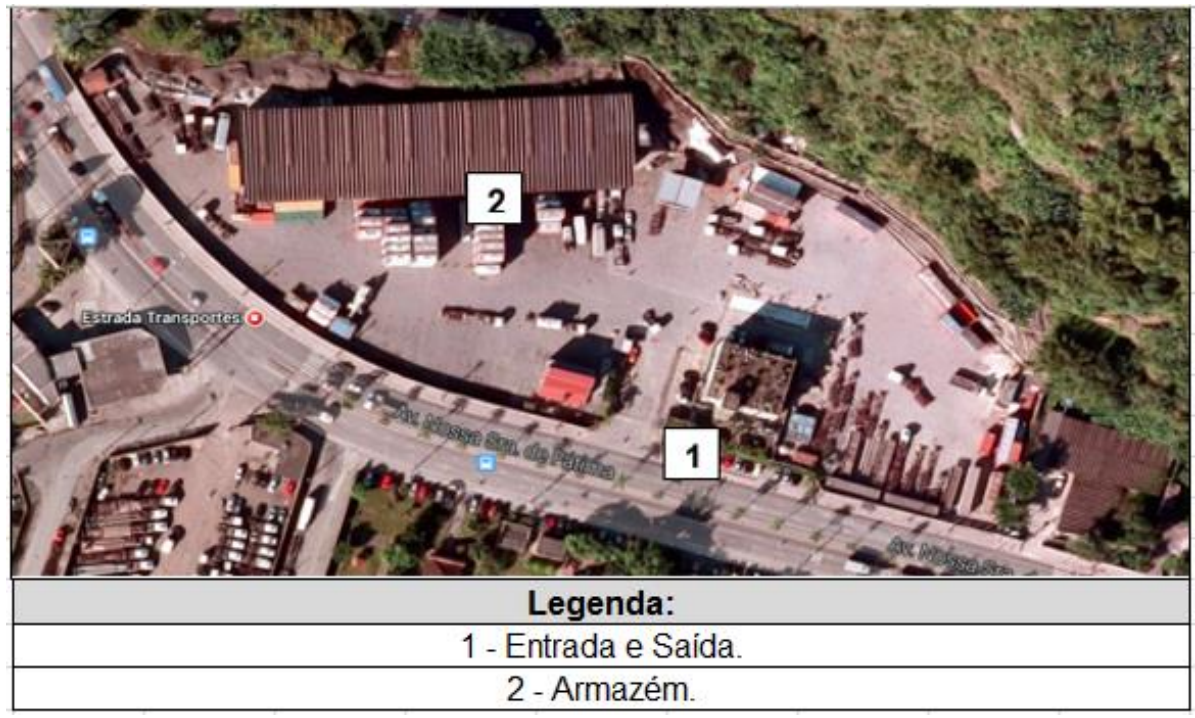

Fonte: Google Maps 
Assim garantindo a otimização do processo de alocação de contêineres e ganhos em produtividade e competitividade com relação ao mercado de atuação da empresa.

\section{ANÁLISE DOS RESULTADOS}

O presente projeto direcionado aos seus processos de movimentação e armazenagem de contêineres pôde ser desenvolvido com base em dados fornecidos pela própria empresa por meio do setor de Atendimento e constatado pela Gerência.

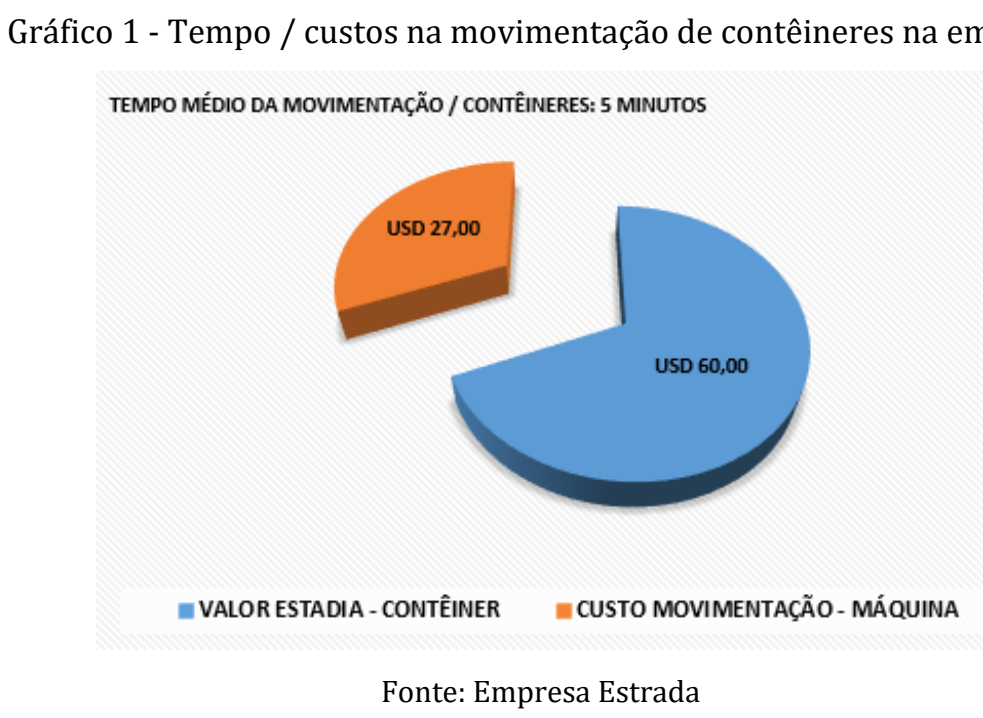

Observe no gráfico 1 acima, o tempo e os custos envolvidos na movimentação dos contêineres sendo tempo médio da movimentação dos contêineres evidenciado por 5 minutos e os respectivos valores em dólares de estadia por contêiner ao dia e o custo da movimentação da máquina.

Gráfico 2 - Representação gráfica da movimentação periódica de contêineres

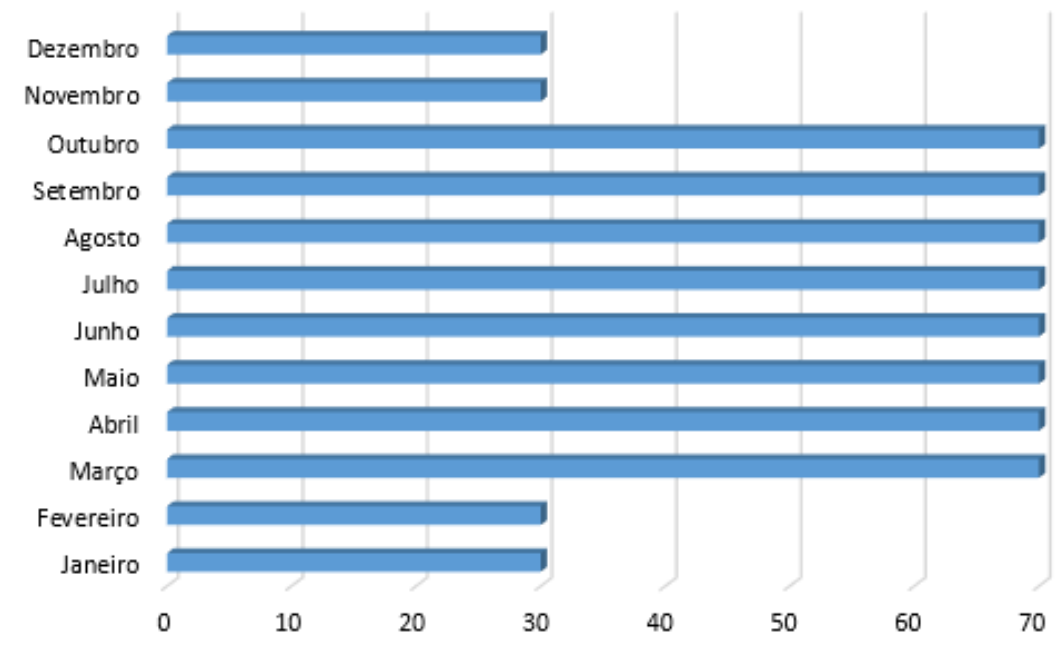

Fonte: Empresa Estrada 
Com relação ao gráfico 2 acima, observa-se a operação da empresa, historicamente, apresenta dois períodos distintos, sendo que de Novembro à Fevereiro de cada período a empresa apresenta sazonalidade de baixa movimentação e de Março à Outubro o período de alta movimentação, que deve-se pela representatividade da safra ser maior nessa época do ano.

Dentro do cenário logístico da relação custo e movimentação foi levantado um assunto que seguramente visualiza a melhora de todo o processo; o uso de tecnologia da informação como ferramenta aliada à empresa, como constatado pelo projeto apresentado como forma de otimização e agregação de valor no serviços prestados pela a empresa Estrada.

\section{PROBLEMÁTICA}

A empresa Estrada, que tem como missão consolidar-se como a melhor empresa nacional de soluções logísticas no transporte de cargas gerais e de Comércio Exterior e mercado interno, tem se preocupado em resolver gargalos que interrompem a eficácia de sua produtividade no momento da prestação de serviços.

Figura 6 - Planta Estrada: Área de atuação

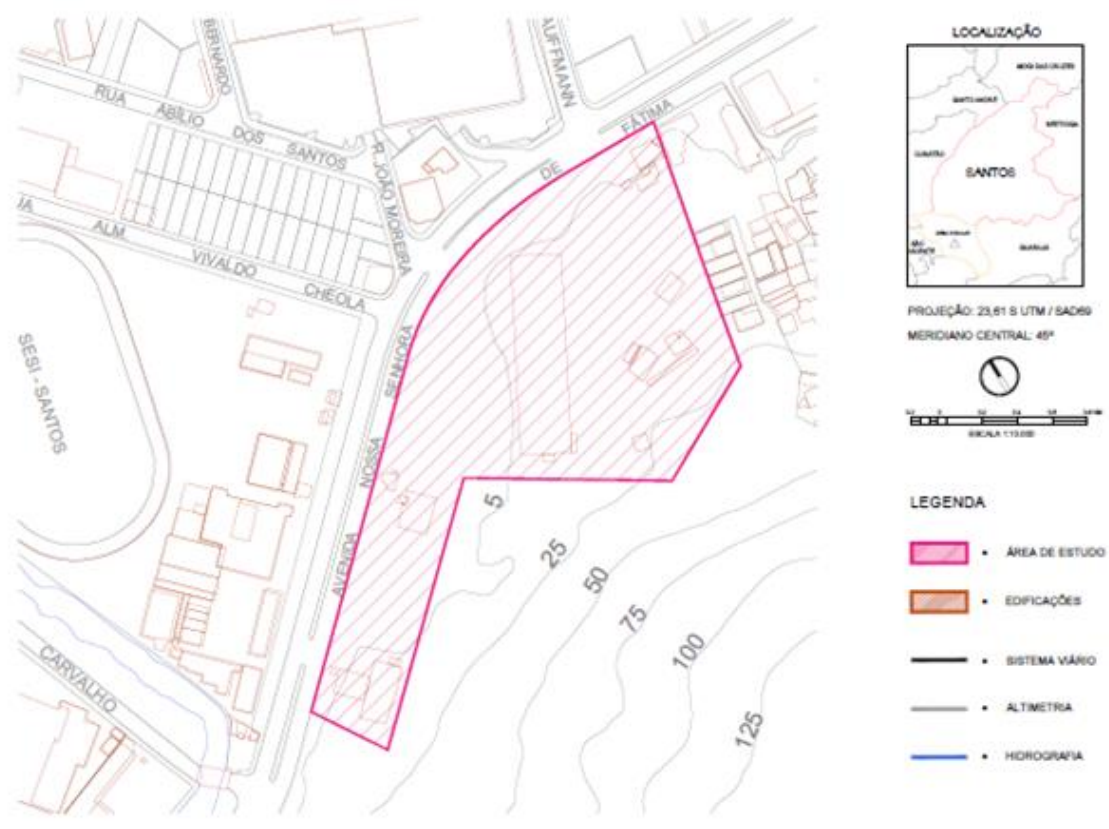

Fonte: Autor

A fase da armazenagem envolvendo a correta alocação de contêineres dentro do terminal é um processo extremamente importante no que tange espaço físico / rendimento da empresa, pois algumas cargas ficam armazenadas por maiores períodos que outras, e, quando não corretamente registradas, identificadas e posicionadas estrategicamente, podem se tornar obstáculos quando se trata de localização e movimentação, gerando um impasse referente a organização e produtividade na empresa.

Desta maneira, o objetivo principal deste projeto é a elaboração de um protótipo de um sistema tecnológico para a melhoria das atividades logísticas na empresa, fazendo-a alcançar facilmente suas metas e objetivos propostos. 


\section{CONSIDERAÇÕES FINAIS}

A probabilidade de que os dados de movimentação apresentados tenham um crescimento considerável, assim como todo o processo logístico e intermodal de cargas. O Porto de Santos, hoje, está em primeiro lugar no ranking latino-americano de movimentação portuária, posto ao qual alcançou pelo grande número de cargas, geral e a granel, que entram e saem do país por meio do complexo santista. E para permanecer nesta posição, é necessário um bom gerenciamento estratégico tanto público quanto privado, que constantemente analise as variáveis internas e externas do mercado antes da tomada de decisão.

“O planejamento estratégico é um esforço para produzir decisões que orientarão as ações da organização. Deve ser simples e claro, e conter a missão, princípios, as metas e objetivos da empresa, com base nas premissas e varáveis internas e externas. As variáveis internas se concentram nos recursos financeiros, humanos e tecnológicos. Apresentam um maior grau de controle, uma vez que as ações sobre elas podem ser imediatas. Já as variáveis externas apresentam maiores riscos e apresentam um menor nível de controle ou nenhum controle. Correspondem ao mercado e aos clientes, à concorrência, à conjuntura social, política e econômica e aos fornecedores". (BERTAGLIA, 2016, p.40).

Projetar um cenário futuro promissor é de fundamental importância, atualmente as constantes mudanças tecnológicas e as mudanças políticas e econômicas tornam os mecanismos de otimização um diferencial de mercado, e o que é visto como viável hoje, torna-se dispensável ou defasado amanhã. Com base nesta realidade estar preparado para o desconhecido, isto é, para o que está por vir, pode ser um fator determinante para sobrevivência ou continuidade da corporação, e é com este propósito que o projeto foi idealizado e, posteriormente, será desenvolvido.

\section{REFERÊNCIAS}

[1] ABRATEC, Disponível em: http://www.abratec-terminais.org.br/estatisticas, Acesso em 02/04/2017 às 17 h55min.

[2] BERTAGLIA, Paulo Roberto. Logística e o Gerenciamento da Cadeia de Abastecimento. 3a ed. São Paulo: Editora Saraiva, 2016, 546 p.

[3] Blog Estrada, Disponível em: http://www.juntosnaestrada.com.br/default.asp?p=sobre-a-gente, Acesso em 28/03/2017 às $14 \mathrm{~h} 35 \mathrm{~min}$.

[4] Bureau International des Containers et du Transport Intermodal, Disponível em: http://www.bic-code.org/, Acesso 21/03/2017 às $13 \mathrm{~h} 12 \mathrm{~min}$.

[5] CHRISTOPHER, Martin. Logística e Gerenciamento da Cadeia de Suprimentos. $3^{\circ}$ ed. São Paulo: Editora Cengage Learning, 2012, 332 p.

[6] ComexBlog.com, Disponível em: http://www.comexblog.com.br/logistica/logistica-portuaria-os-portosmais-movimentados-do-brasil-e-do-mundo, Acesso em 19/03/2017 às 12h46min.

[7] DIAS, Marco Aurélio P. Logística, Transporte e Infraestrutura: Armazenagem, Operador Logístico, Gestão via TI, Multimodal. $1^{\circ}$ ed. São Paulo: Editora Atlas, 2012, 340 p.

[8] Estrada, Disponível em: http://www.estrada.com.br/site.aspx/Nossa-Empresa, Acesso em 15/03/2017 às 09h35min.

[9] ILOS, Disponível em: http://www.ilos.com.br/web/analise-de-mercado/relatorios-de-pesquisa/supplychain-finance/, Acesso em 03/03/2017 às 11h36min.

[10] Lloyd's List, Disponível em: https://www.lloydslist.com/ll/incoming/article534477.ece, Acesso em 03/03/2017 às $10 \mathrm{~h} 23 \mathrm{~min}$. 
[11] MCKEAN, David. Estratégia Direto ao Ponto. 1aㅡ ed. São Paulo: Editora Saraiva, 2012, 269 p.

[12] Porto sem Mistério, Disponível em: http://portosemmisterio.com.br/logistica-2/movimentacao-deconteiner-crescera-em-media-74-ano-ate-2021-no-brasil/, Acesso em 25/02/2017 às 10h33min.

[13] Secretaria de Portos, Disponível em: http://www.portosdobrasil.gov.br/home-1/estatisticas, Acesso em 25/02/2017 às $10 \mathrm{~h} 12 \mathrm{~min}$. 


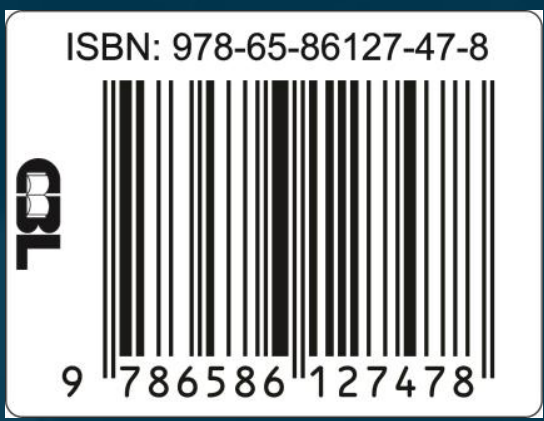

